\title{
Chemical and Biological Aspects of Marine Sponges from the Family Mycalidae
}

Authors

Affiliations
Leesa J. Habener ${ }^{1}$, John N. A. Hooper ${ }^{2}$, Anthony R. Carroll ${ }^{1}$

${ }^{1}$ Environmental Futures Research Institute, School of Environment, Griffith University, Gold Coast, Australia

2 Biodiscovery and Geosciences Program, Queensland Museum, Brisbane, Australia
Key words

- Mycale

- Mycalidae

- sponges

- Porifera

- bioactivity

- alkaloids

- polyketides

- chemical diversity received Sep. 3, 2015

revised January 29, 2016

accepted February 6, 2016

Bibliography

DOI http://dx.doi.org/

10.1055/s-0042-103245

Published online March 22.

2016

Planta Med 2016; 82: 816-831

(c) Georg Thieme Verlag KC

Stuttgart · New York .

ISSN 0032-0943

Correspondence

Prof. Anthony R. Carroll

Environmental Futures

Research Institute

Griffith University

Gold Coast, QLD 4222

Australia

Phone: + 61755529187

Fax: +61755527785

a.carroll@griffith.edu.au

\section{Abstract \\ $\nabla$}

Sponges are a useful source of bioactive natural products. Members of the family Mycalidae, in particular, have provided a variety of chemical structures including alkaloids, polyketides, terpene endoperoxides, peptides, and lipids. This review highlights the compounds isolated from Mycalid sponges and their associated biological activities. A diverse group of 190 compounds have been reported from over 40 specimens contained in 49 references. Over half of the studies have reported on the biological activities for the compounds isolated. The polyketides, in particular the macrolides, displayed potent cytotoxic activities $(<1 \mu \mathrm{M})$, and the alkaloids, in particular the 2,5-disubstituted pyrrole derivatives, were associated with moderate cytotoxic activities (1-

\section{Introduction}

The Porifera is one of the most studied marine phyla for the discovery of novel bioactive natural products [1]. This is not surprising considering the diversity associated with marine sponges, with the phylum comprising over 8500 described species [2,3]. Knowledge of species diversity within the Porifera remains incomplete and the number of species discovered still continues to climb at a constant rate $[2,3]$. One diverse sponge family that has proven to be a source of biologically important natural products is the family Mycalidae. The family, characterised by the presence of palmate anisochelae spicules, has a worldwide distribution with close to 250 currently valid species $[2,4]$. Species are organised into two genera, either the larger and more diverse genus Mycale, or the smaller genus Phlyctaenopora [4]. Due to the high diversity within these genera, they are further divided into subgenera. The genus Mycale is comprised of the eleven subgenera,
$20 \mu \mathrm{M})$. The pyrrole alkaloids and the cyclic peroxides appear to be phylogenetically restricted to sponges and thus might prove useful when applied to sponge taxonomy. The observed diversity of chemical structures suggests this family makes a good target for targeted biodiscovery projects.

\section{Abbreviations}

$\nabla$

HDAC: histone deacetylase

PC: $\quad$ principal component

PKS-NRPS: hybrid polyketide synthase and nonribosomal synthase

WPD: World Porifera Database

Supporting information available online at http://www.thieme-connect.de/products

Mycale (Mycale), Mycale (Aegogropila), Mycale (Anonomycale), Mycale (Arenochalina), Mycale (Carmia), Mycale (Grapelia), Mycale (Naviculina), Mycale (Oxymycale), Mycale (Paresperella), Mycale (Rhaphidotheca), and Mycale (Zygomycale), and the smaller genus Phlyctaenopora is subdivided into two subgenera, Phlyctaenopora (Phlyctaenopora) and Phlyctaenopora (Barbozia) [4].

This diverse sponge family has received attention from natural product chemists in pursuit of bioactive natural products with a range of structural classes being reported from its members. These include alkaloids such as 2,5-disubstituted pyrrole derivatives, polyketides such as trisoxazole macrolides, terpenoids such as the mycaperoxides with a 1,2-dioxane attached to bicyclic terpene moieties, and lipids such as the glycosidic steroids, mycalosides. These compounds have also displayed a range of biological activities with cytotoxic, antibacterial, antifungal, and antiviral activities reported. This rich chemical diversity suggests that the family Mycalidae shows promise 


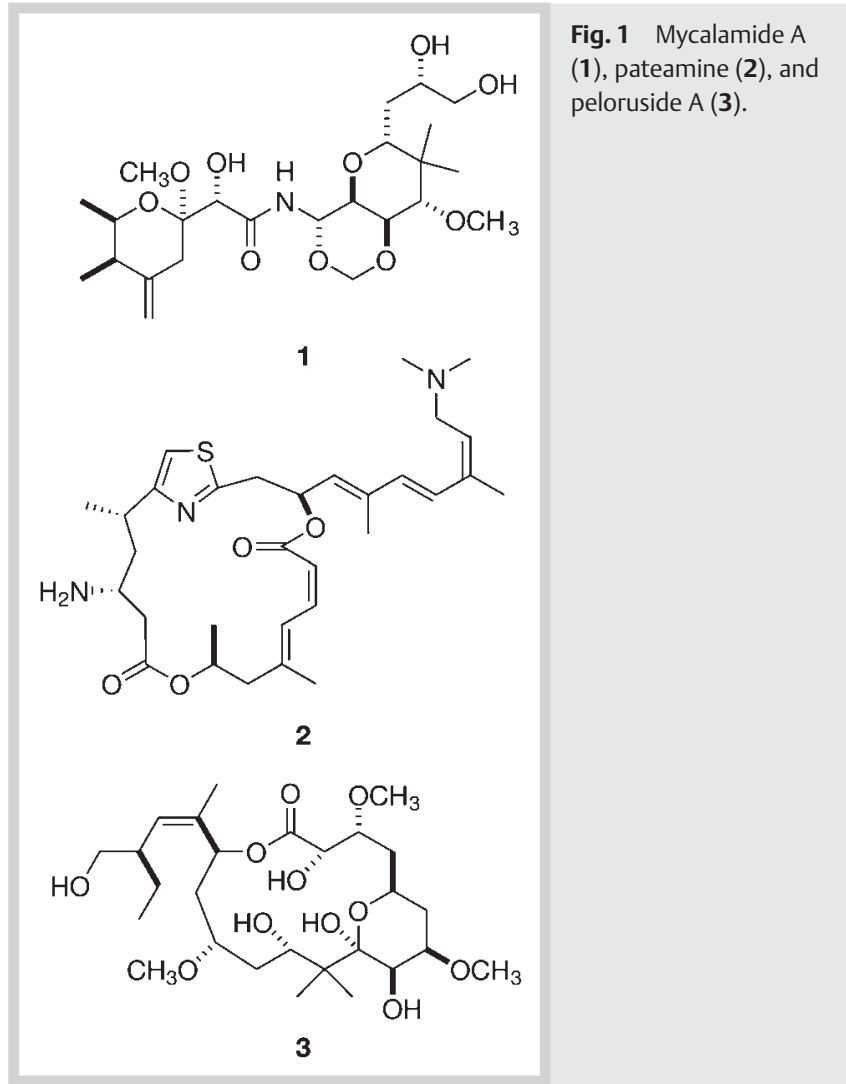

as a source for potential drug candidates. Good examples of this are the compounds mycalamide A (1) [5], pateamine (2) [6], and peloruside A (3) [7] ( Fig. 1), all isolated from the sponge Mycale (Carmia) hentscheli displaying potent cytotoxicity and yet all these compounds are structurally unrelated.

This review documents the known chemical diversity of the natural products isolated from members of the family Mycalidae. As a result of undertaking this survey, two important questions can be addressed. Firstly, is the family Mycalidae a good resource for biodiscovery? Secondly, are any of the compounds or compound classes reported in the family Mycalidae potentially useful for taxonomic purposes? This review provides a summary of all compounds reported from members of the family Mycalidae prior to June 2015 and their associated biological activity. Sponges identified as members of the family Mycalidae include those that possess currently accepted species names and previous synonyms presented in the WPD [2]. Species names referred to in this review are those currently accepted according to the WPD and include subgenera classifications. Where these are different from the original source, the originally used species name is also provided.

\section{A note to the reader}

The data summarised here is what is currently available and reported in the literature. Care should be taken when interpreting the patterns presented here. The compounds classes, species, and geographic regions sampled are largely due to research efforts (a summary of research efforts in terms of number of publications within a country over time is available as Fig. 25 and Table 5S, Supporting Information). Patterns in biological activity should be interpreted with care as the isolation of bioactive compounds (especially cytotoxic ones) could be biased based on targeted re-

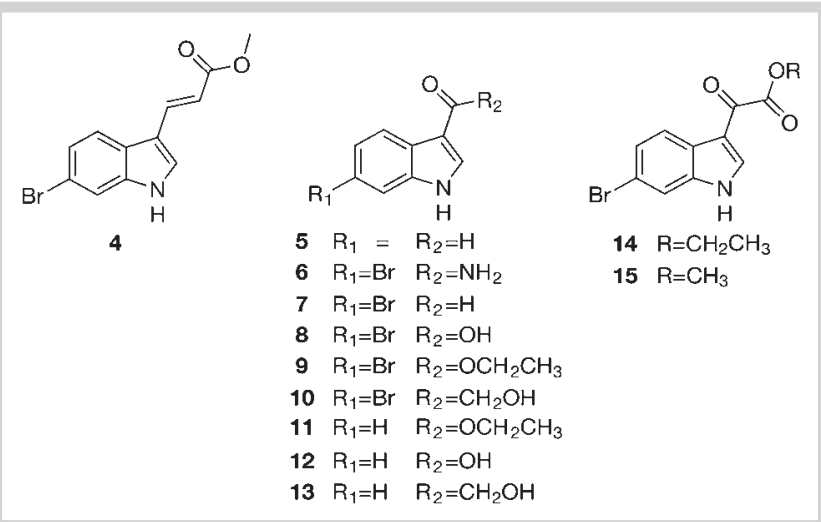

Fig. 2 Chemical structures of monoindole alkaloids.

search efforts. Additionally, the biological activity data is by no means exhaustive since many compounds have no activity reported because they have not been tested. As the binomial nomenclature ensures there is a universally recognisable scientific name, the inclusion of the subgenus in species names is not required and therefore seldom used in chemical publications. However, since the genus Mycale is so taxonomically diverse, for the purpose of assessing the distribution of reported chemistry among this genus, the accepted subgenera for each species (according to the WPD) have also been referred to. Finally, given the nature of sponge taxonomy there is often a limited ability to appropriately identify samples and misidentifications can be misleading.

\section{Chemical Constituents of the Family Mycalidae}

\section{Alkaloids}

Indole alkaloids

A series of twelve monoindole alkaloids ( Fig. 2) substituted at position 3 and some brominated at position 6 have been reported in three Mycalid species collected from China, Japan, and India [8-10]. The first report of a monoindole alkaloid from a Mycalid source was the known bromoindole (4) from the sponge M. (Aegogropila) adhaerens collected from Japan [9]. The known 3-formyl indole (5) was isolated from both an Indian specimen of $M$. (Carmia) tenuispiculata [8] as well as a Chinese specimen of $M$. (Carmia) fibrexilis [10]. This Chinese specimen also yielded another ten indole alkaloids comprised of one new brominated indole (6) with six other known brominated indoles (7-10, 14, and 15) and four known indoles (5 and 11-13) [10].

Brominated indoles have been reported widely in the sponge class Demospongiae [10] in the orders Dictyoceratida, Poecilosclerida, Tetractinellida, and Suberitida. In particular from the genera Dysidea [11], Iotrochota [12,13], Tedania (Tedania) [14], Corallistes [15], Pleroma [16], Hymeniacidon [17], Pseudosuberites [18], and Spongosorites [19]. Brominated indoles have also been reported in other non-sponge marine taxa, for example, 12 from the ascidian Leptoclinides durus [20] and 14 from bacteria isolated from marine sediment [21]. Indole $\mathbf{4}$ has displayed nematocidal activity against the parasite Haemochus contortus [17]. 


\section{Pyrrole derivatives}

The pyrrole derivatives are the largest group of compounds isolated from the family Mycalidae, with a total of 67 compounds of which 62 have been reported for the first time (- Figs. 3 and 4). Most of these (55 compounds) are represented by 5-alkylpyrrole2-carboxaldehyde derivatives and some of these have been given the trivial names mycalazals (vary in alkyl chain length, branching, and saturation) and mycalenitriles (like mycalazals but with a terminal nitrile group). Structural diversity within this group results from variation in the length and structure of the alkyl chain. Variation includes alkyl branching, one or multiple double bonds, and the presence of other functional groups (e.g., terminal nitriles). The remaining 12 compounds, commonly known as mycalazols, have the $\mathrm{C}-2$ aldehyde moiety reduced to a primary alcohol.

The first pyrrole derivatives isolated from Mycalid sponges were 16 from M. (Mycale) monanchorata (originally reported as $M y$ calecarmia monanchorata) and $\mathbf{1 7}$ from M. (Carmia) mytilorum, both collected in India [22]. Both of these compounds, however, were first isolated as a mixture with $\mathbf{1 8}$ (and one other pyrrole derivative) from the sponge Hymeniacidon sp., order Suberitida (as Laxosuberites sp.) [23]. Following this two more 5-alkylpyrrole-2-carboxaldehydes, mycalazals 1 and 2 (19 and 20), and twelve 5-acyl-2-hydroxymethylpyrroles, mycalazols 1-12 (2132 ), were characterised from M. (Carmia) micracanthoxea collected from Spanish waters [24].

In 1999, compounds $\mathbf{1 6}$ and $\mathbf{1 7}$ were reisolated from a Venezuelan M. (Carmia) microsigmatosa specimen together with ten new 5-alkylpyrrole-2-carboxaldehydes (33-42) and one new 5-alkylpyrrole-2-carboxaldehyde containing a terminal nitrile (43) [25]. In the same paper, the six compounds $16,17,35,36,40$, and 41 were co-isolated from the sponge Desmapsamma anchorata (order Poecilosclerida). An Indian specimen of M. (Carmia) mytilorum yielded two new 5-alkylpyrrole-2-carboxaldehydes (44 and 45) [26], and another Indian species, M. (Carmia) tenuispiculata, was the source of three new compounds including the pyrrole derivative 46, mycaleoxime (47), and the nitrile terminate pyrrole 48 [8]. Mycaleoxime (47) differs from the other pyrrole derivatives by the presence of a carbonyl group adjacent to the pyrrole nucleus and a terminal aldoxime group. The new compounds mycalazals 3-13 (49-59) and mycalenitriles 1-3 (60-62) (distinguished by a terminal nitrile group) were found in $M$. (Carmia) cecilia from Mexico [27], with the eight known pyrrole derivatives $16,18,35,36,41,43,63$, and $64[23,25]$.

In 2009, 16 and $\mathbf{4 6}$ were reisolated from an Indonesian M. (Carmia) phyllophila [28]. The 5-alkylpyrrole-2-carboxaldehydes 16, $17,35,36,43,49,60$, and 61 were again reisolated from a member of the Mycalidae family, this time from an unidentified $M$. (Carmia) sp. from Palau together with twelve new mycalenitriles 4-14 (65-75), and seven new mycalazals 14-20 (76-82) [29]. Finally, in 2013, an unidentified Mycale sp. from China also produced 17 [30]. Related structures (e.g., 83) have been reported from a soft coral-sponge association comprised of a soft coral of the genus Telesto and an unidentified sponge [31], and compound $\mathbf{6 4}$ has also been reported from the sponge Oscarella lobularis (order Homosclerophorida) [32].

Many of these pyrrole derivatives have displayed various biological activities. Mycalazal 2 (20) and the mycalazols 1-12 (21-32) showed cytotoxicity against a panel of cell lines (P388, SCHABEL, A549, HT29, and MEL28) with $E_{50}$ values of less than $10 \mu \mathrm{g} / \mathrm{mL}$, and many of these compounds displaying $\mathrm{ED}_{50}$ values of less than $2.5 \mu \mathrm{g} / \mathrm{mL}$. Of these, mycalazol 6 (26) was the most active with an

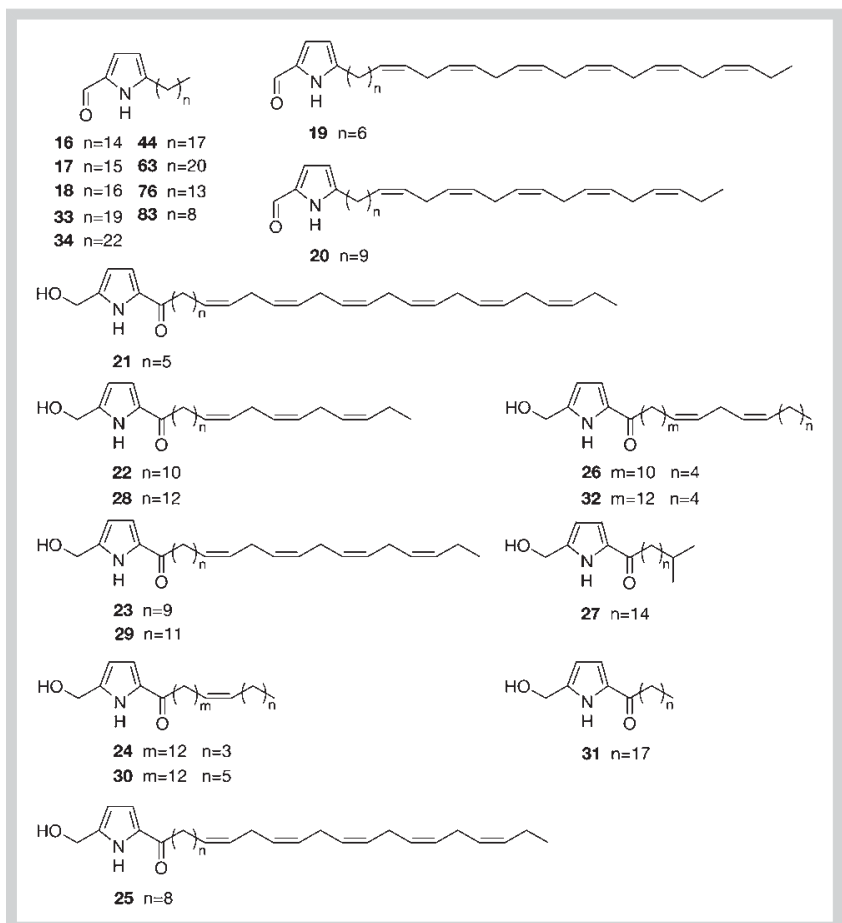

Fig. 3 Chemical structures of 2,5-disubstituted pyrrole derivatives.

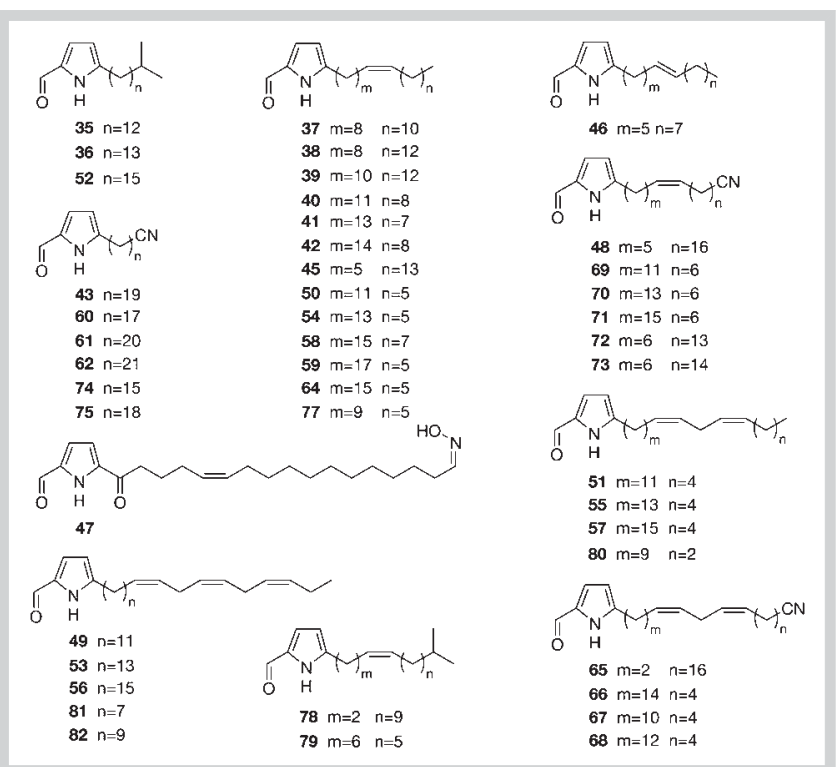

Fig. 4 Chemical structures of 2,5-disubstituted pyrrole derivatives.

$\mathrm{ED}_{50}$ value of $2 \mu \mathrm{g} / \mathrm{mL}$ for MEL28 and $1 \mu \mathrm{g} / \mathrm{mL}$ for the remaining cell lines [24]. The nitrile $\mathbf{4 3}$ was an active inhibitor of the proliferation of the parasite Leishmania mexicana with an $\mathrm{LD}_{50}$ value of $12 \mu \mathrm{g} / \mathrm{mL}$ [25]. A library of 22 pyrrole-2-carboxaldehydes including the mycalazals 3-13 (49-59), the mycalenitriles 1-3 (60-62), and the known pyrrole-2-carboxaldehydes 16, 18, 35, 36, 41, 43, 63, and 64 were screened against a panel of cell lines (LN-caP, IGROV, SK-BR3, SK-MEL-28, A-549, K-562, PANCI, LOVO, and HeLa cell lines), which resulted in some interesting structure activity observations (see [27] for specific $\mathrm{GI}_{50}$ values). The authors 


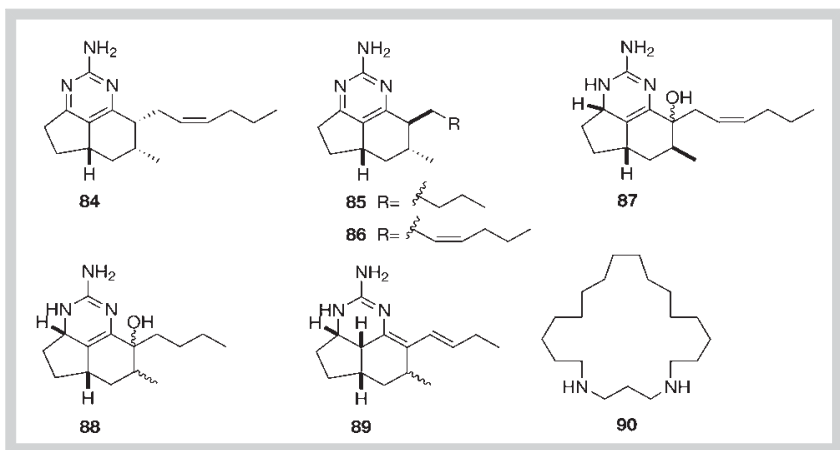

Fig. 5 Chemical structures of mirabilin alkaloids and 1,5-diazacyclohenicosane.

compared the LN-caP cell line inhibition with the structures of the compounds and found that activity was associated with the presence of a single double bond, activity decreased with three double bonds, and was lost completely with two double bonds or saturated alkyl chains [27]. As a mixture, the pyrroles 16 and 46 inhibited the growth of mouse lymphoma cells (L5178Y) with an $\mathrm{IC}_{50}$ value of $1.8 \mu \mathrm{g} / \mathrm{mL}$ [28]. Mycalenitriles showed inhibition of hypoxia-induced factor (HIF-1) activation. Mycalenitriles 6 (67) and 7 (68) were the most active with $\mathrm{IC}_{50}$ values of 7.8 and $8.6 \mu \mathrm{M}$, respectively. Mycalenitriles 1 (60), 5 (66), 8 (69), and 13 (74) were moderately active with $\mathrm{IC}_{50}$ values ranging from 10 $20 \mu \mathrm{M}[29]$.

\section{Other alkaloids}

Mirabilins A-F (84-89, 0 Fig. 5) were reported from the sponge M. (Arenochalina) mirabilis (originally reported as Arenochalina mirabilis) [33]. This is the only report of guanidine tricyclic alkaloids from a member of the family Mycalidae. Several of these mirabilins have since been reported in other sponge species including mirabilins A (84), C (86), and F (89) from Biemna laboutei [34], a Clathria (Isociella) sp. [35], a Batzella sp. [36], and Monanchora arbuscula $[37,38]$. Mirabilins are members of a structurally diverse class of compounds that have been reported in a range of taxa, including both marine and terrestrial microorganisms, invertebrates, and plants (see [39] and previous reviews in series). Related tricyclic alkaloids with a guanidine moiety have been reported in five other sponge genera including Acanthella [40], Batzella $[34,36,41]$, Clathria (Isociella) $[35,42]$, Monanchora $[37,38$, 43,44], and Ptilocaulis [45].

Some of these mirabilins have been reported to possess moderate biological activities. Mirabilin A (84) has displayed antimalarial activity against Plasmodium falciparum ( IC $_{50}$ value of $20.7 \mu \mathrm{M}$ ) [34], and mirabilin B (85) has been reported to have antifungal activity against the strain Cryptococcus neoformans $\left(\mathrm{IC}_{50}\right.$ value of $7.0 \mu \mathrm{g} / \mathrm{mL}$ ) as well as antiprotozoal activity against Leishmania donovani $\left(\mathrm{IC}_{50}\right.$ value of $17 \mu \mathrm{g} / \mathrm{mL}$ ) [38]. Other members of this structure class have also displayed antimalarial activity [34] and several have displayed cytotoxicity to tumour cells $[34,37,41]$. A new cyclic amine 1,5-diazacyclohenicosane (90, O Fig.5) was isolated from a Mycale sp. collected from Kenya [46]. Moderate cytotoxic activity was reported against human lung, colon, and breast tumour cell lines (A549, HT29, MDA-MB-231) with $\mathrm{GI}_{50}$ values in the micromolar range (ranging from 5.07-5.74 $\mu \mathrm{M}$ ) [46].

\section{Polyketides}

Macrolides

The trisoxazole family of macrolides ( $\bullet$ Figs. 6 and 7) are macrocyclic lactones with a trisoxazole unit (three contiguous oxazoles) and a side chain with a formyl enamine terminal moiety $[47,48]$. In total, ten structures have been reported from sponges identified as members of the family Mycalidae. Mycalolides A-C (91-93) were first characterised from a Japanese Mycale sp. [49] followed by the reisolation of mycalolides A (91) and B (92) from M. (Aegogropila) adhaerens of Japanese origin [9]. Mycalolide A (91) has been reported in other Japanese Mycalid specimens including M. (Aegogropila) magellanica [47], M. izuensis [50], and an unidentified Mycale sp. [51] and was reported together with mycalolide C (93) in the non-Mycalid sponge Sarcotragus sp. [52]. Mycalolide C (93) has also been reported from the coral Tubastrea faulkneri together with the first characterisations of mycalolides D (94) and E (95) [53], which to date have not been reported from Mycalid (or any) sponges. Mycalolide B (92) has also been reported in other Japanese Mycalid specimens, including M. (Aegogropila) magellanica [47] and M. izuensis [50]. Mycalolides share structural similarity to other trisoxazole macrolides, for example, mycalolide A (91) is a hybrid between halichondramide (96) and ulapualide A (97) [49].

Two sulphur-containing mycalolides, thiomycalolide A (98) and B (99), were reported from another Japanese specimen of Mycale sp. [54]. Several hydroxylated derivatives of mycalolide A (91) and $B(\mathbf{9 2})$ have also been characterised from Japanese sponges, including 30-hydroxymycalolide A (100), 32-hydroxymycalolide A (101), and 38-hydroxymycalolide B (102) from M. (Aegogropila) magellanica [47] and $M$. izuensis [50]. The M. izuensis specimen also yielded 30,32-dihydroxymycalolide A (103) [50]. An unidentified Mycale sp. yielded 30-hydroxymycalolide A (100) in addition to the new compound secomycalolide A (104) in which one of the oxazole rings has been cleaved, resulting in a ring opening of the macrocyclic lactone [51]. The trisoxazole family of macrolides occurs in members of five sponge orders including Tetractinellida (Pachastrissa nux [55] and Jaspis sp. [56]), Suberitida (Halichondria sp. [57-59]), Chondrosiida (Chondrosia corticata [60]), Poecilosclerida (a number of Mycale sp.), and order Dictyoceratida (Sarcotragus sp. [52]). Additionally, trisoxazole macrolides have also been reported from other non-sponge sources such as the egg masses of the nudibranch Hexabranchus sp. [58, 61-63]. Trisoxazole macrolides have displayed a range of biological activities, including cytotoxic, proteasome inhibiting, actin-depolymerising, antimalarial, and antifungal activities. Mycalolides A-C (91-93) have reported cytotoxic activity against B-16 melanoma cells ( $\mathrm{IC}_{50}$ values ranging from $0.5-1.0 \mathrm{ng} / \mathrm{mL}$ ) [49], mycalolide $B$ (92) has displayed activity against HeLa cells ( IC $_{50}$ value of $0.0035 \mu \mathrm{g} / \mathrm{mL}$ ) [64], and mycalolides C (93) and D (94) have shown moderate activity (average $\mathrm{LC}_{50}$ values of 2.5 and $0.6 \mu \mathrm{M}$, respectively) against the National Cancer Institute's 60-human tumour cell line panel [53]. The sulphated and hydroxylated mycalolides have also shown considerable cytotoxicity. Thiomycalolides A (98) and B (99) are both active ( $\mathrm{IC}_{50}$ value of $18 \mathrm{ng} / \mathrm{mL}$ for both compounds) against P388 cells [54]. The hydroxylated mycalolides 30-hydroxymycalolide A, 32-hydroxymycalolide A, and 38-hydroxymycalolide $B(\mathbf{1 0 0}-\mathbf{1 0 2})$ have shown activity against L1210 cells (with $\mathrm{IC}_{50}$ values of $0.019,0.013$, and $0.015 \mu \mathrm{g} / \mathrm{mL}$ respectively) [47] and 30,32-dihydroxymycalide A (103) has shown activity against HeLa cells ( $\mathrm{IC}_{50}$ value of $\left.2.6 \mathrm{ng} / \mathrm{mL}\right)$ [50].

The mycalolides secomycalolide A (104), mycalolide A (91), and 30-hydroxymycalolide A (100) have also displayed proteasome 


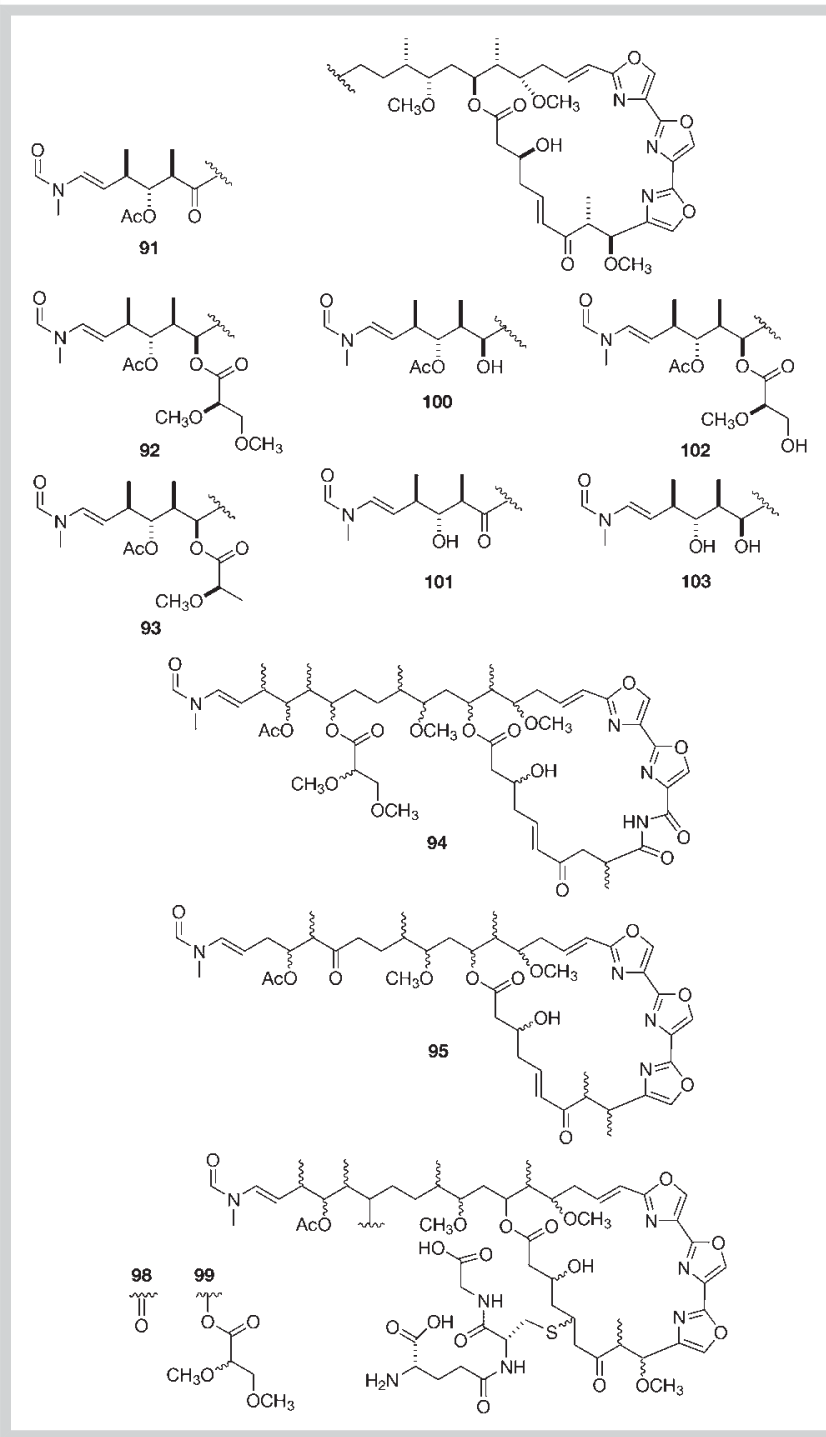

Fig. 6 Chemical structures of macrolide polyketides.

inhibitory activity in an assay using a chymotrypsin-like substrate with $\mathrm{IC}_{50}$ values of 11,30 , and $45 \mu \mathrm{g} / \mathrm{mL}$, respectively [51]. Additionally, the activity of mycalolide B (92) has been further explored in an effort to characterise both the actin depolymerising activity [65] and actomyosin inhibitory activity [66]. Through the exploration of an analogue of mycalolide B (92), Suenaga et al. [64] documented that the side chain portion of the compound is responsible for actin-depolymerisation activity and that the macrocyclic ring is essential to cytotoxicity.

Six other unrelated macrolides with various biological activities have been isolated from the family Mycalidae ( $\bullet$ Figs. 1 and 8). The Japanese specimen of $M$. (Aegogropila) adhaerens afforded a 13-deoxytedanolide (105) [9], which is related to the original compound tedanolide (106) first isolated from the sponge Tedania ignis in 1984 [67] ( Fig. 8). Further analogues of tedanolide have been isolated from other sponge species of the genera Ircinia [68] and Candidaspongia [69]. 13-Deoxytedanolide (105) has displayed cytotoxicity to P388 murine leukaemia cells with an $\mathrm{IC}_{50}$ value of $94 \mathrm{pg} / \mathrm{mL}$ [9] and protein synthesis inhibition [70]. Tedanolide (106) is known for possessing potent cytotoxicity when tested against cell cultures of human carcinoma of naso-

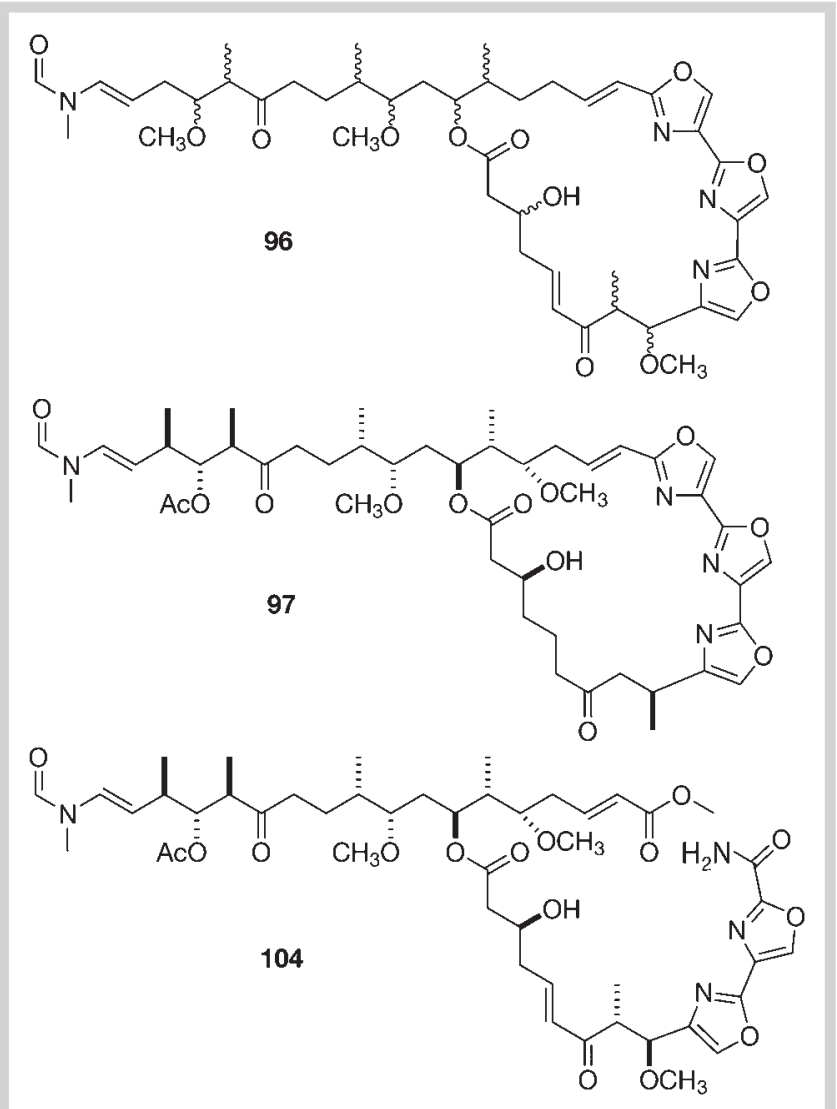

Fig. 7 Chemical structures of macrolide polyketides.

pharynx $\left(\mathrm{ED}_{50}\right.$ value of $\left.0.25 \mathrm{ng} / \mathrm{mL}\right)$ and in vitro lymphotytic leukaemia ( $E_{50}$ value of $16 \mathrm{pg} / \mathrm{mL}$ ) and can cause S-phase arrest at a concentration of $0.01 \mu \mathrm{g} / \mathrm{mL}$ [67].

The 19-membered thiazole-containing dilactone macrolide pateamine (2, $\bullet$ Fig. 1) was isolated from two specimens of Mycale sp. and a specimen of M. (Carmia) hentscheli from New Zealand [6, 7, 71]. Pateamine (2) has attracted considerable interest due to its potent biological activities (see [72] for summary of progress of $\mathbf{2}$ as a drug target). Pateamine (2) has displayed potent cytotoxicity against $\mathrm{P} 388$ murine leukaemia $\left(\mathrm{IC}_{50}\right.$ value of $0.15 \mathrm{ng} / \mathrm{mL}$ ) and antifungal activity against Candida albicans, Trichophyton mentagrophytes, and Cladosporium resinae (MIC of $1 \mu \mathrm{g} / \mathrm{disk}, 20 \mathrm{ng} / \mathrm{disk}$, and $0.4 \mu \mathrm{g} / \mathrm{disk}$, respectively) [6]. Pateamine (2) also showed promise as an immunosuppressive agent with an $\mathrm{IC}_{50}$ value of $0.46 \mathrm{nM}$ in an interleukin-2 reporter gene assay [73].

Peloruside A (3, $\odot$ Fig. 1), a polyoxygenated 16-member macrolide, was characterised from a New Zealand specimen of Mycale sp. [7]. The natural congener peloruside $B(\mathbf{1 0 7}, 0$ Fig. 8) was characterised from a New Zealand specimen of $M$. (Carmia) hentscheli [74]. Peloruside A (3) was reisolated from another New Zealand specimen of $M$. (Carmia) hentscheli together with the two new structures peloruside $C$ (108) and D (109) [71]. Pelorusides share some structural similarity to the geminal dimethyls and polyhydroxylation observed in mycalamides (next section) and the macrolide ring of pateamine (2), however, they are not biochemically related [7].

Peloruside A (3) was active against P388 murine leukaemia cells at approximately $18 \mathrm{nM}$ [7] and peloruside B (107) was active ( $\mathrm{IC}_{50}$ value of $71 \mathrm{nM}$ ) against human ovarian carcinoma (1 A9 
cells) [74]. Pelorusides A-D (3, 107-109) were active against human myeloid leukaemia (HL-60 cells) with $\mathrm{IC}_{50}$ values of $10 \mathrm{nM}$, $33 \mathrm{nM}, 221 \mathrm{nM}$, and $2 \mu \mathrm{M}$, respectively [71,74]. Pelorusides have also been shown to arrest cells in the $\mathrm{G}_{2} / \mathrm{M}$ phase of the cell cycle, suggesting that the mitotic microtubules are the target for observed cytotoxicity $[71,74,75]$. Peloruside A (3) has received large interest due to its ability to alter microtubulin dynamics, leading to cell cycle arrest and apoptosis (see [76] for a review of activity studies), which has led to its consideration as a potential anticancer agent [75].

\section{Nitrogen-containing polyketides}

During the search for antiviral compounds, mycalamides A and B ( 1 and 110, 0 Figs. 1 and 9) were discovered after the extract of a New Zealand Mycale sp. displayed in vitro antiviral activity [5, 77]. Since then, mycalamide A (1) has been reisolated from several other New Zealand specimens of Mycale sp. [7,78] and M. (Carmia) hentscheli $[71,74,79]$ together with additional mycalamides. These include mycalamide D (111) from a Mycale sp. [78] and mycalamide E (112) from M. (Carmia) hentscheli [79]. Mycalamides have also been isolated in other taxa such as the sponge Stylinos n. sp. (mycalamides A and D ( 1 and 112) [80]) and the ascidian Polysyncraton sp. (mycalamide A (1) [81]). Mycalamides have displayed antiviral activity against Herpes simplex type-1 and Polio type-1 viruses active at 3.5-5.0 ng/disk for mycalamide A (1) and 1.0-2.0 ng/disk for mycalamide B (110) [77]. Several mycalamides have shown cytotoxicity against various cell lines with most $\mathrm{IC}_{50}$ values at sub-5 nM $[78,79,82$, 83]. Notably, mycalamide A (1) was active in the sub-nanomolar range ( $\mathrm{IC}_{50}$ values from $0.50-0.65 \mathrm{nM}$ against cell lines LLCPK1, H441, and SH-SY5Y) $[78,83]$ and mycalamide B (110) was active in the nanomolar range ( $\mathrm{IC}_{50}$ values from $0.6-1.5 \mathrm{nM}$ against cell lines P388, HL-60, A549, and HT-29) [82].

The six mycapolyols A-F (113-118, O Fig. 9), metabolites of PKSNRPS, were isolated from a Japanese specimen of M. izuensis [84]. Several other compounds have been reported in the literature that contain the dolapyrrolidone unit; a good example of this is dolastatin 15 (119) isolated from the mollusc Dolabella auricularia [85]. Related compounds have been isolated from various organisms, namely molluscs, sponges, and cyanobacteria, however, these compounds are all thought to be of cyanobacterial origin and either accumulated in animals or are partially modified [8588]. Mycapolyols showed potent cytotoxicity against HeLa human cancer cells ( $\mathrm{IC}_{50}$ values from $0.06-0.90 \mu \mathrm{g} / \mathrm{mL}$ ) [84], and the related dolastatin 15 (119) is known for its potent cytotoxicity (ED 50 value of $0.0024 \mu \mathrm{g} / \mathrm{mL}$ against P388 cells [85]).

\section{Other polyketides}

Three acetogenins (120-122, 0 Fig. 10) have been reported from the species M. (Aegogropila) rotalis $[89,90]$. Since then, 120 and 121 have been reisolated from the red alga Laurencia paniculata [91] and other structures similar to 122 , such as 123 , have been reported from Laurencia intricate [92]. The brominated dihydroisocoumarin hiburipyranone (124) was isolated from the Japanese $M$. (Aegogropila) adhaerens and has exhibited cytotoxicity against P388 murine leukaemia cells with an $\mathrm{IC}_{50}$ value of $0.19 \mu \mathrm{g} / \mathrm{mL}[9]$.

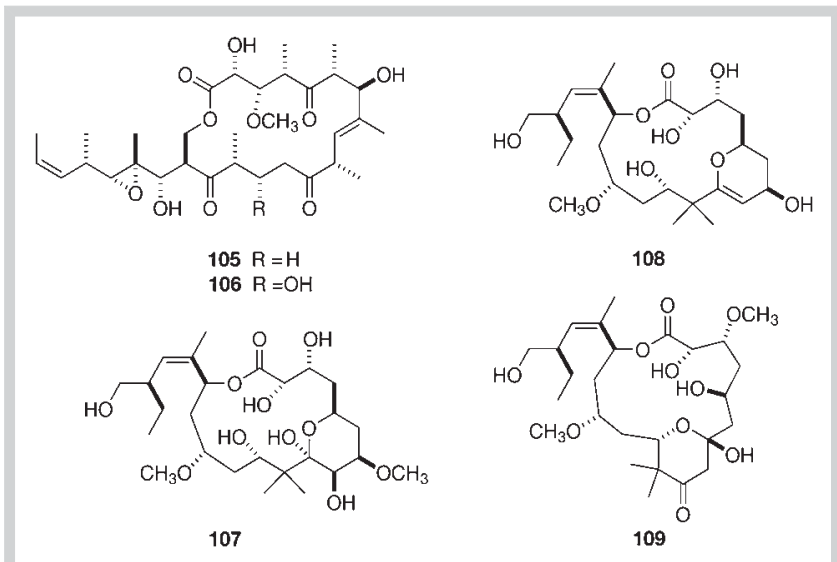

Fig. 8 Chemical structures of macrolide polyketides.

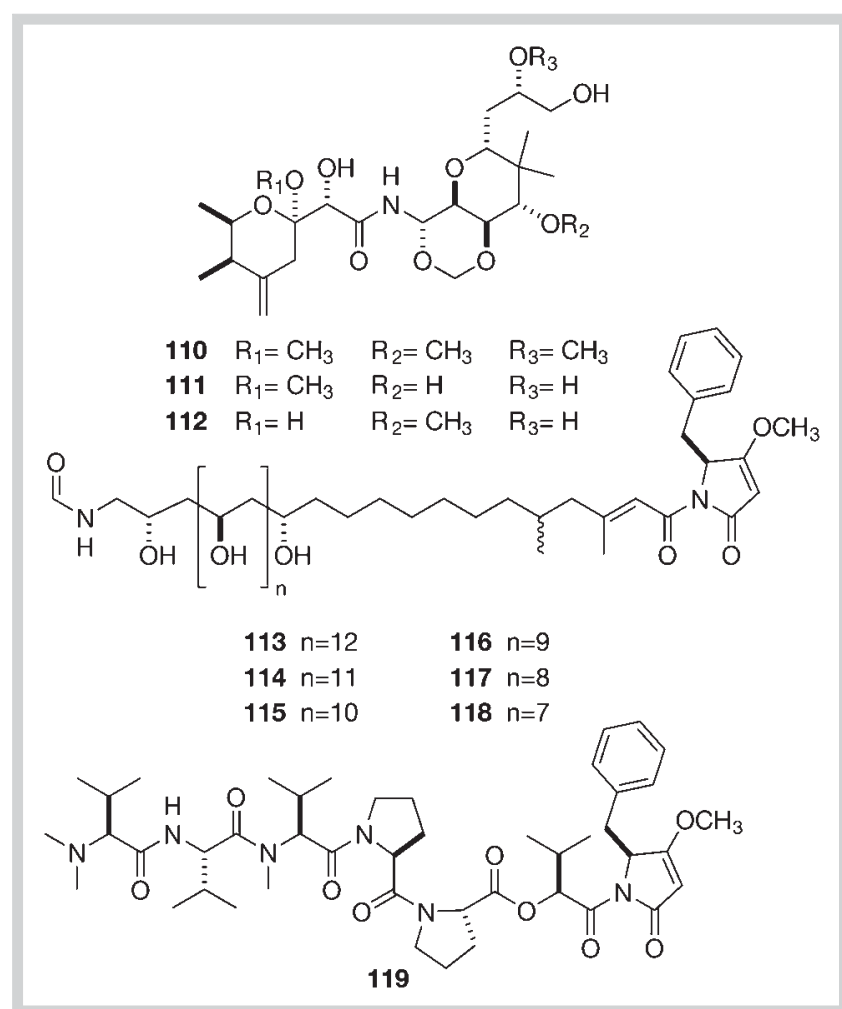

Fig.9 Chemical structure of mycalamides and mycapolyols.

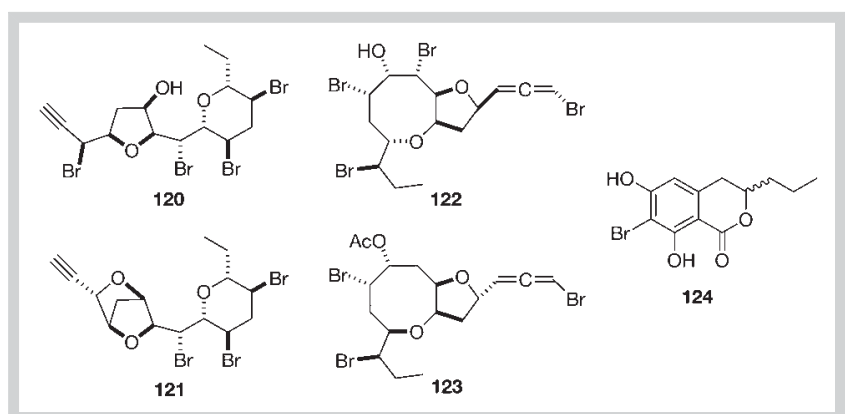

Fig. 10 Chemical structures of other polyketides. 
Terpenes and terpenoids

\section{Sesquiterpenes}

Five aromatic bisabolene sesquiterpenes ( $\bullet$ Fig. 11) were isolated from an Australian specimen of M. (Arenochalina) sp. (as Arenochalina sp.) [93]. Two of these compounds, (+)-curcudiol (125) and (+)-curcuphenol (126), have been characterised previously. The other three isomeric structures, the C-4' hydroxyl epimers (127) and 3',4'-didehydrocurcudiol (128), were reported for the first time [93]. Since the first report of $(-)$-curcuphenol and related derivatives (e.g., 125 and 126) from the gorgonian Pseudopterogorgia rigida [94], related compounds have been reported from sponge sources including Discus flavus [95] and Myrmekioderma styx [96]. The new compounds 127 and 128 were later reported together with (-)-curcuphenol and several other aromatic bisabolenes from a gorgonian source, Pseudopterogorgia rigida [97].

(+)-Curcuphenol (126) has been tested for various activities including cytotoxicity, antifungal, and antibacterial properties. Antitumour properties were recorded against P388 murine leukaemia ( $\mathrm{IC}_{50}$ value of $7 \mu \mathrm{g} / \mathrm{mL}$ ) and human tumour cell lines. Minimum inhibition concentrations were $10 \mu \mathrm{g} / \mathrm{mL}$ for lung (A549) cells and $0.1 \mu \mathrm{g} / \mathrm{mL}$ for both colon (HCT-8) and mammary (MDAMB) tumour cell lines [95]. When tested against Candida albicans and Cryptococcus neoformans, (+)-curcuphenol (126) displayed antifungal activity ( $\mathrm{IC}_{50}$ value of approximately $15 \mu \mathrm{g}$ / $\mathrm{mL})[95,96]$ and showed broad inhibition against filamentous fungi in disc assays [98]. Antibacterial activity was recorded against both Staphylococcus aureus and methicillin-resistant S. aureus ( $\mathrm{IC}_{50}$ value of less than $20 \mu \mathrm{g} / \mathrm{mL}$ ) [96]. (+)-Curcudiol (125) showed weak antifungal activity against filamentous fungi [98] and C. albicans (MIC value of $250 \mu \mathrm{g} / \mathrm{mL}$ ) [95].

\section{Diterpenes}

The first Mycalid diterpenes, rotalin A (129) and B (130) ( Fig. 11), were characterised from a Sicilian specimen of the species M. (Aegogropila) rotalis [99]. Rotalin A (129) resembles the labdane family of plant-derived diterpenoids containing a rearranged labdane skeleton [99], while rotalin B (130) is a brominated diterpene. The new diterpene mycgranol (131), with an isocopalane skeleton, was reported in the species M. (Arenochalina) aff. graveleyi collected from Kenya [100]. The isocopalanes are a class of diterpenoids that exist in two enantiomeric forms and are restricted to the marine environment [101]. These compounds have been reported from organisms such as nudibranchs (e.g., Anisodoris fontaini [102]) and sponges (e.g., Coelocarteria cfr. singaporensis [101] and Spongia zimocca [103]). No activity has been reported for these Mycalid diterpenes and little activity has been reported for the related compounds.

\section{Cyclic peroxides}

Cyclic peroxides are norsesterterpenes containing a 1,2-dioxane ring ( Fig. 12) that usually exist as carboxylic acids, but are more easily isolated as their methyl esters and have displayed various bioactivities [104-106]. The first cyclic peroxide isolated from a Mycalid source was enantio-sigmosceptrellin A (132) isolated from an Australian M. (Aegogropila) cf. ancorina [107]. This is the enantiomer of sigmosceptrellin A (133), which was originally isolated from the sponge Diacarnus laevis (originally reported as Sigmosceptrella laevis) $[108,109]$ but where the absolute configuration was later corrected by Capon and MacLeod [107]. Later, 132 was again isolated from an Australian M. (Grapelia) ancorina together with the two new cyclic peroxides 134 and 135 that are

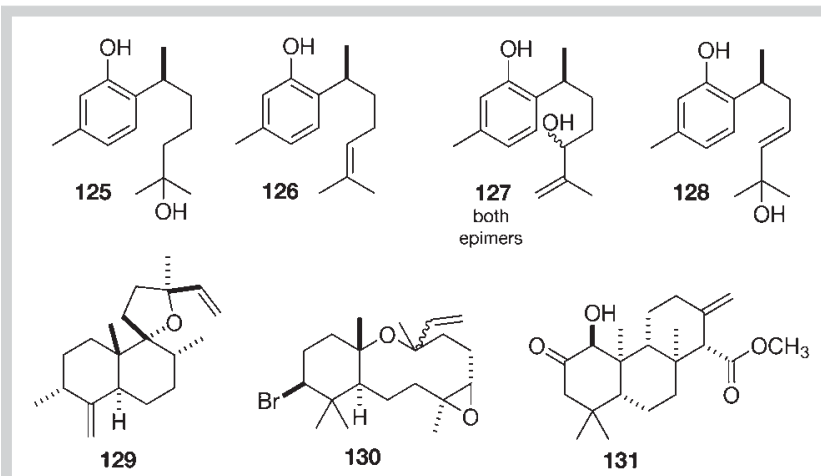

Fig. 11 Chemical structures of aromatic sesquiterpenes and diterpenes.

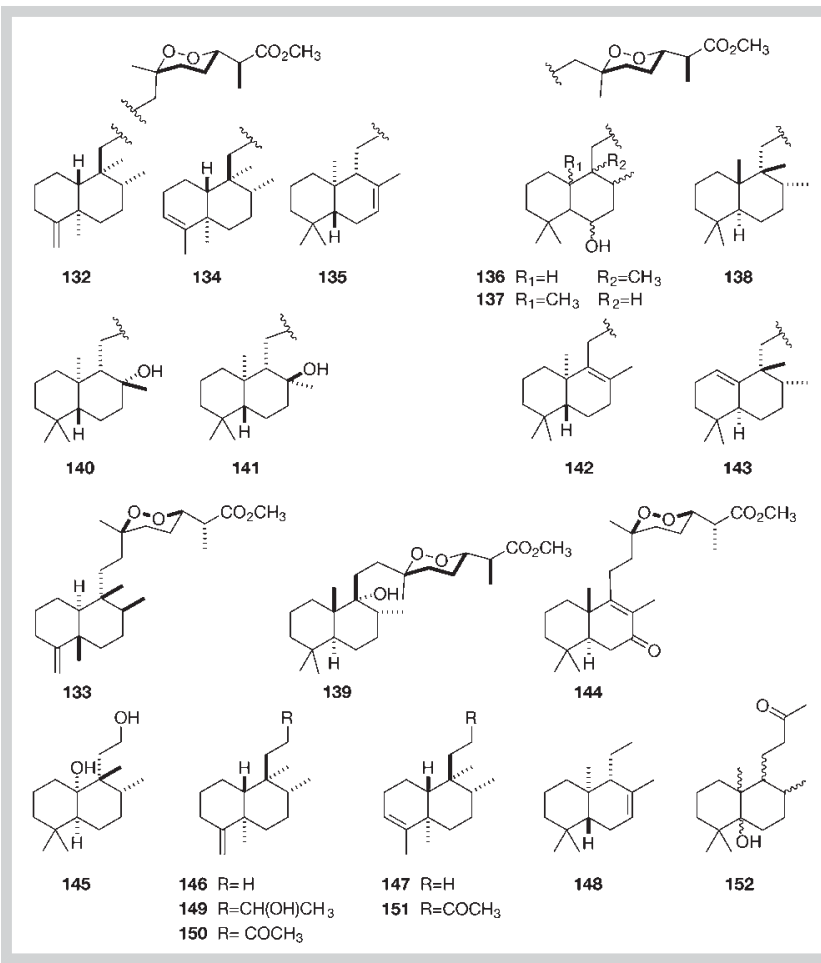

Fig. 12 Chemical structures of cyclic peroxides and related norterpenes and norterpenoids.

isomeric with enantio-sigmosceptrellin A (132) [110]. The Australian sponge $M$. (Carmia) cf. spongiosa was the source of two new cyclic peroxides that were later named mycaperoxide $\mathrm{E}$ (136) and F (137) [104]. A Thai Mycale sp. yielded the two cyclic peroxides mycaperoxide $A$ (138) and $B(139)$ [111] and two further mycaperoxides, C (140) and D (141), were isolated from an Australian Mycale sp. in addition to the known compounds enantio-sigmosceptrellin A (132), 134, and 135 [106]. The known mycaperoxide F (137) was reisolated from an Australian Mycale sp., and the new mycaperoxide $G$ (142) was characterised from another individual of unidentified Mycale sp. [112]. Mycaperoxide $H$ (143), isolated together with mycaperoxide B (139), was characterised from another Thai Mycale sp. [113], and mycaperoxide A (138) was reisolated from an Indonesian M. (Arenochalina) euplectellioides [114]. 
Cyclic peroxides have also been reported in other sponge genera, mainly Diacarnus [108, 109,115,116], Latrunculia [107,117], Negombata [118] and Sigmosceptrella [119], which are all from the order Poecilosclerida. Bicyclic peroxides that share similar structural characteristics to the mycaperoxides include the sigmosceptrellins (e.g., sigmosceptrellin A 133) isolated from the sponge Diacarnus laevis $[108,109]$ and diacarperoxides (e.g., diacarperoxide F 144) from the sponge Diacarnus megaspinorhabdosa [116].

Mycaperoxides A (138) and B (139) inhibited the growth of bacteria (Bacillus subtilis and S. aureus), showed antiviral activity with $\mathrm{IC}_{50}$ values in the range of $0.25-1.0 \mu \mathrm{g} / \mathrm{mL}$ (against Vesicular stomatitis virus and Herpes simplex virus type-1), and showed cytotoxicity with $\mathrm{IC}_{50}$ values ranging from $0.5-1.0 \mu \mathrm{g} / \mathrm{mL}$ (against P388, A549, and HT-29 cell lines) [111]. Mycaperoxide A (138) has also displayed cytotoxicity with an $\mathrm{IC}_{50}$ value of $0.45 \mu \mathrm{M}$ (against six tumour cell lines in an MTT assay), which was in contrast to the inactivity ( $\mathrm{IC}_{50}$ value of $10 \mu \mathrm{M}$ ) of euplectellodiol (145), a norterpenoid (discussed in the next section) that is thought to be an oxidative degradation product of mycaperoxide A (138) [114]. This highlights the importance of the presence of a 1,2-dioxane ring for biological activity [114]. Mycaperoxide $\mathrm{H}$ (143) has also displayed activity as a cytotoxic agent with an $\mathrm{IC}_{50}$ value of $0.8 \mu \mathrm{g} / \mathrm{mL}$ against HeLa cells [113].

\section{Norterpenes and norterpenoids}

Bicyclic norterpenes and norterpenoids (145-152, @ Fig. 12) are biogenetically related to cyclic peroxides, either as oxidative degradation products or through related biosynthetic pathways yielding similar structures. Six compounds were reported from an Australian Mycale sp., these are comprised of the three $\mathrm{C}_{16}$ bicyclic norterpenes 146,147 , and 148 as well as three $C_{18}$ bicyclic norterpenoids, one containing a hydroxyl group (149) and two containing ketones (150 and 151) [106]. A third $C_{18}$ bicyclic norterpenoid ketone (152) was reported in another specimen of an Australian Mycale sp. [112] and a $\mathrm{C}_{16}$ dihydroxy bicyclic norterpenoid, euplectellodiol (145), was isolated from an Indonesian specimen of M. (Arenochalina) euplectellioides [114].

The $C_{18}$ norterpenoids 149-151, co-isolated with enantio-sigmosceptrellin A (132) and cyclic peroxide 134, share the same bicyclic moiety [106]. The $C_{18}$ norterpenoid ketone 152 shares a common bicyclic moiety with mycaperoxide F (137) [112], and the $C_{16}$ norterpenoid euplectellodiol (145) reflects the same bicyclic system as mycaperoxide A (138) [114]. The only comparative study to assess the biological activity of cyclic peroxides and their norterpene equivalents was that of euplectellodiol (145), which showed no cytotoxicity in contrast to its related cyclic peroxide mycaperoxide A (138), which displayed potent cytotoxicity. This provides evidence that the cyclic peroxy functionality is essential for bioactivity [114].

\section{Lipids}

\section{Ceramides}

The new ceramide 153 ( $\odot$ Fig. 13) was reported in an Indian specimen of $M$. (Carmia) mytilorum [26]. The known $C_{22}$-ceramide 154 was reported in a Chinese specimen of Mycale sp. [30] and was originally isolated from the marine sponge Haliclona koremella [120]. Ceramides have displayed a range of bioactivities, including antiviral, cytotoxic, antifungal, antifouling, antitumour, immunostimulatory, and anti-inflammatory activities (documented in review [121]). In the original isolation, ceramide 154 displayed antifouling activity through inhibiting the rate of

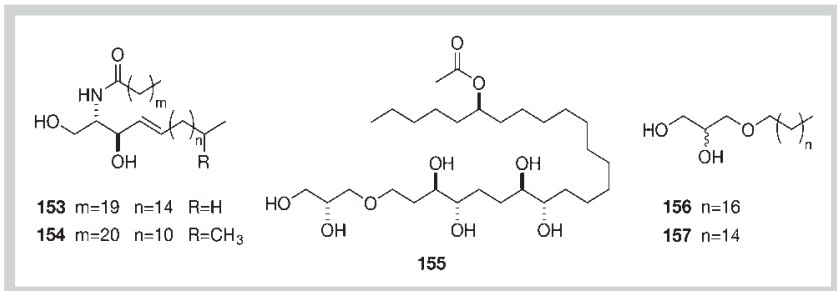

Fig. 13 Chemical structures of ceramides and ether lipids.

attachment and germination of macroalgae (Ulva conglobata) spores [120].

\section{Ether lipids}

A new polyoxygenated monoalkyl glyceryl ether, mycalol (155, - Fig. 13), was isolated and characterised from the species M. (Oxymycale) acerata collected from Antarctica [122]. The original structure was revised through total synthesis [123]. Two known alkyl glycerols have been reported in two Mycalid specimens. Batyl alcohol (156) was reported in an M. (Carmia) mytilorum specimen from India [26], and chimyl alcohol (157) was reported in a Chinese specimen of Mycale sp. [30]. Mycalol (155) is a unique ether lipid, however, the related batyl alcohol (156) and chimyl alcohol (157) have been widely reported since they were the first isolated in the $1920 \mathrm{~s}$ (see reference [124] for review of ether lipids).

Mycalol (155) has shown specific cytotoxicity against anaplastic thyroid carcinoma (ATC) with $\mathrm{IC}_{50}$ values ranging from 3.8$15.7 \mu \mathrm{M}$ for a range of human ATC-derived cell lines (FRO, FRO-asHMGA1, ACT1, 8505c) [122]. Mycalol (155) was also tested against other solid tumour lines showing cytotoxicity in the micromolar range to $\mathrm{HCT} 116$ ( $\mathrm{IC}_{50}$ value of $10.9 \mu \mathrm{M}$ ), but was inactive to the other cell lines tested (GEO, GEO + HMGA1, OVCAR8, and MCF7) [122].

\section{Sterols}

In total, 11 common sterols, one epidioxy sterol, and one steroidal lactone (158-170, O Fig. 14) have been reported in members of the family Mycalidae. The first two cholesterol derivatives 158 and $\mathbf{1 5 9}$ were reported from the Indian sponge M. (Carmia) mytilorum [22]. The compound 158 was also isolated together with cholesterol (160) and seven other sterols (161-167) in the free sterol fraction of a specimen of $M$. (Arenochalina) laxissima from Cuba [125]. Cholesterol (160) was also reported from a Chinese Mycale sp. with an epidioxy sterol (168) [30] after which 168 was isolated from a second Chinese Mycale sp. [126]. Another common sterol (169) was isolated from M. (Arenochalina) euplectellioides from Egypt [127]. An unidentified Australian Mycale sp. yielded the steroidal lactone mycalone (170), which possess an unusual side chain containing a six-membered lactone [128]. All of the 11 common sterols reported in the family Mycalidae have been reported in many other sponges. Most sponges contain a mixture of common sterols with a dominance of $C_{27}, C_{28}$, and $\mathrm{C}_{29}$ sterols.

The $5 \alpha, 8 \alpha$-epidioxy 168 reported from Mycale sp. was originally reported from a sea pen (Virgularia sp.) and a mollusc (Adalaria sp.) [129], and since its first report it has been isolated from other marine invertebrates including a sea anemone (Metridium senile [130]), a tunicate (Dendrodoa grossularia [131]), and a sponge (Homaxinella sp. [132]). Epidioxy sterols have shown biological 
activities with 168 showing toxicity against brine shrimp larvae $\left(\mathrm{LD}_{50}\right.$ value of $4.7 \mu \mathrm{g} / \mathrm{mL}$ [30]) and inhibitory effects against Foxo3 a ( IC $_{50}$ value of $32.8 \mu \mathrm{g} / \mathrm{mL}$ ), HMGCR-GFP ( IC $_{50}$ value of $6.8 \mu \mathrm{g} / \mathrm{mL}$ ), and NF- $k$ B-luciferase ( $\mathrm{IC}_{50}$ value of $16.3 \mu \mathrm{g} / \mathrm{mL}$ ) assays [126]. Mycalone (170) is a novel steroidal lactone, an unusual side chain that contains a 6-membered lactone ring has also been observed in other sterols such as $\mathbf{1 7 1}$ isolated from the root of the plant Trichodesma indicum. This compound showed antimicrobial activity against gram-positive and gram-negative bacteria and fungi (MICs ranging from 4.8-19.2 $\mu \mathrm{g} / \mathrm{mL}$ ) [133].

\section{Steroid glycosides}

Eleven new steroid oligoglycosides, mycalosides A-K (172-182, - Fig. 15), have been characterised from a Cuban M. (Arenochalina) laxissima $[125,134,135]$. The aglycones of mycalosides $\mathrm{A}-\mathrm{H}$ (172-179) consist of a polyhydroxylated $\Delta^{5}$ steroid, and mycaloside I (180) consists of a polyhydroxylated $\Delta^{7}$ steroid [125]. Additionally, mycalosides $\mathrm{F}, \mathrm{G}$, and $\mathrm{H}$ (177-179) possess a ketone group at position C-15 on the sterol nucleus [125]. Steroidal and tetracyclic triterpenoid glycosides have been isolated from several sponge orders including Tetractinellida, Poecilosclerida, Axinellida, and Haplosclerida. In addition to those isolated from the family Mycalidae, glycosides have been reported in other genera of the order Poecilosclerida, including the Ulosa [136], Pandaros [137], and Ectyoplasia [138]. Mycalosides A-I (172-180) have displayed activity as spermostatics, inhibiting the fertilisation of sea urchin (Strongylocentrotus nudus) eggs, with individual glycosides showing $\mathrm{EC}_{50}$ values of $32 \mu \mathrm{g} / \mathrm{mL}$ [125]. Sponge glycosides have shown biological activities leading to the conclusion that they can serve multiple ecological roles such as feeding deterrents, prevention of biofilm formation, chemical signalling, and allelopathy (see [139] for a review of activities).

\section{Peptides}

Five new cyclic tetrapeptides, azumamides A-E (183-187, - Fig. 16), were reported from the Japanese species M. izuensis [140]. These structures are comprised of three $\alpha$-amino acids (Phe, Ala, Val, or Tyr) and the final residue is a $\beta$-amino acid residue with either a terminal amide or carboxylic acid [140]. Marine sponges are a source of diverse peptides having been reported widely throughout the phylum with a range of biological activities (see [141] for a review of bioactive sponge peptides). Cyclic peptides are commonly observed as fungal metabolites [142144]. Sponges often form associations with fungi and it has been speculated that the azumamides could originate from a spongeassociated fungal source rather than the sponge itself [145].

The azumamides, and other cyclic tetrapeptides, have received interest due to their bioactivities [146]. Of particular interest is the potent inhibitory action against the enzyme HDAC reported to be a good target for cancer treatment. Azumamides A-D (183-186) showed inhibitory activity in the nanomolar range ( $\mathrm{IC}_{50}$ values of $0.045,0.11,0.11$, and $0.064 \mu \mathrm{M}$, respectively) and azumamide $\mathrm{E}$ (187) was slightly less potent ( $\mathrm{IC}_{50}$ value of $1.3 \mu \mathrm{M}$ ) [140].

\section{Nucleosides and nucleobases}

Two new nucleosides ( Fig. 16), mycalisines A (188) and B (189), were characterised in a Mycale sp. collected from Japan [147]. These compounds inhibited cell division of fertilised starfish (Asterina pectinifera) eggs [147]. The mycalisines belong to a class of nucleosides containing a pyrrolopyrimidine ring structure that have been widely reported [147-149]. Aside from the genus

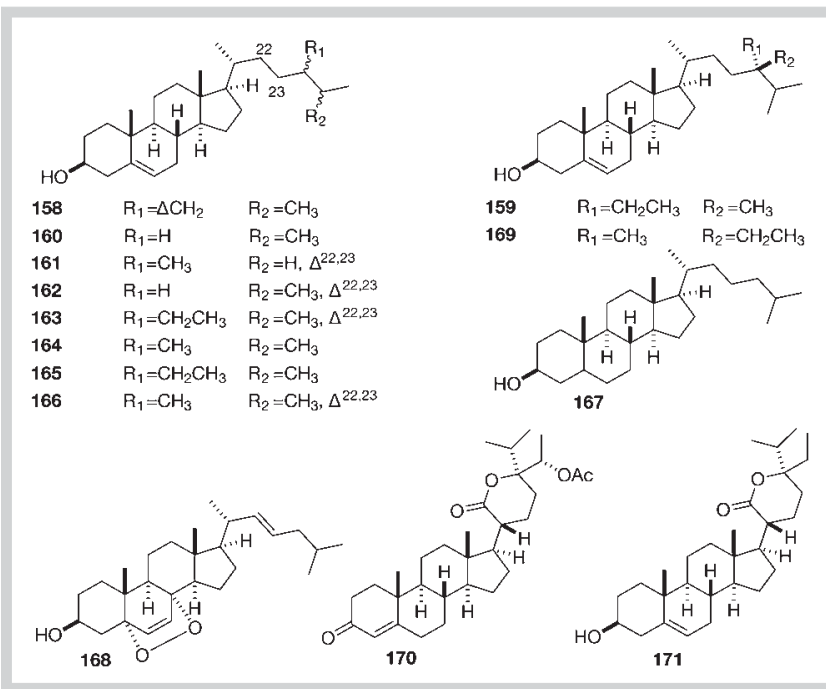

Fig. 14 Chemical structures of sterols.

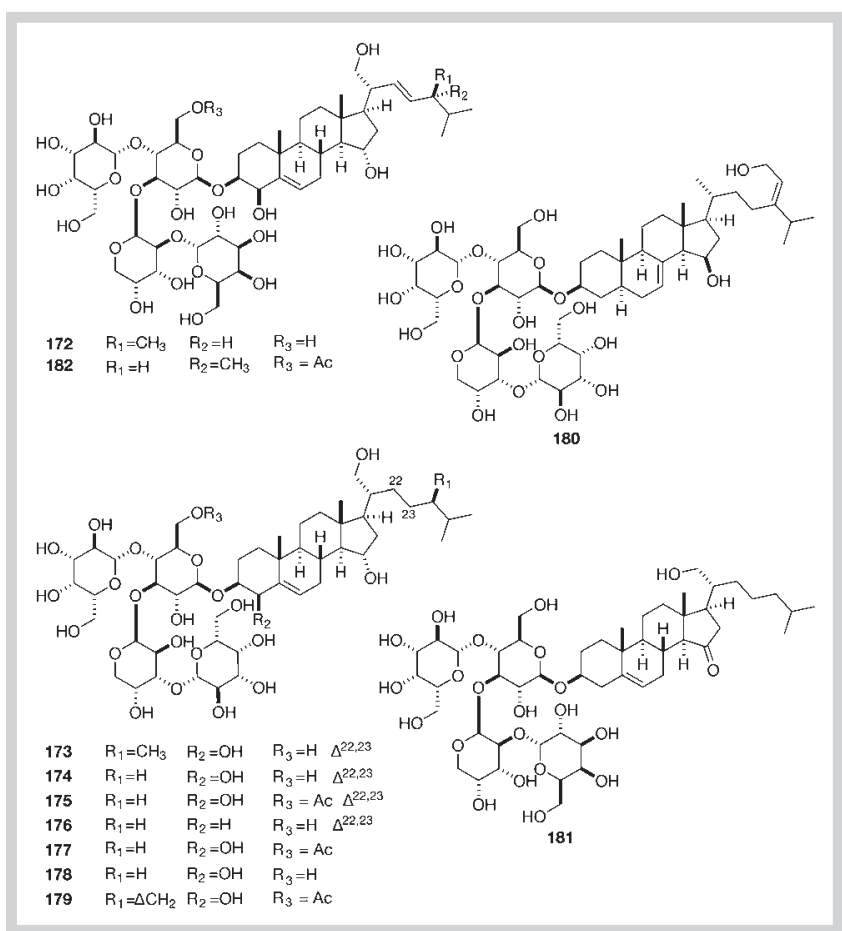

Fig. 15 Chemical structures of steroid glycosides.

Mycale, nucleosides have been reported from two other sponge genera, Echinodictyum (order Axinellida) and Jaspis (order Tetractinellida) [149]. The known deoxynucleoside thymidine (190) was reported in an Indian specimen of M. (Carmia) tenuispiculata [8], and thymine (191) and uracil (192) were reported in a Mycale sp. collected from China [30].

\section{Others}

The remaining compounds isolated from Mycalid sponges are small known organic molecules (193-201, - Fig. 16). A fatty acid methyl ester, methyl henicosanoate (193), benzoic acid (194), and 4-hydroxybenzoic acid (195) as well as dibutyl phthalate (196) 
(dibutyl phthalate is a plasticiser and most likely an artefact from the isolation procedure) were reported from a Chinese specimen of Mycale sp. [30]. In addition to this, $p$-hydroxyphenylacetic acid (197) was reported in an Indian specimen of M. (Carmia) mytilorum in combination with a known tetrahydrophan derivative (198) [26]. Finally, three fatty acids (199-201) have been reported from the Red Sea sponge M. (Arenochalina) euplectellioides [127].

\section{Chemical Diversity of Sponges of the Family Mycalidae $\checkmark$}

In 2007, a computational method, ChemGPS-NP, to explore the biologically relevant chemical space of natural products using 35 calculated molecular descriptors from SMILES codes was reported $[150,151]$. The online tool allows one to evaluate biologically relevant chemical properties such as size, lipophilicity, polarity, and hydrogen bond capacity. Through principal components analysis (PCA), the tool produces score predictions that can be used to map chemical properties in multidimensional space. Each principal component (PC) corresponds to particular physicochemical properties, for example, the second principal component (PC2) comprises aromatic- and conjugation-related properties, while the third principal component (PC3) comprises lipophilicity, polarity, and hydrogen bonding capacity $[150,151]$. The SMILES codes for the published Mycalid compounds were submitted to ChemGPS-NP for analysis and their chemical diversity was plotted using the PC2 and PC3 descriptors ( $\odot$ Fig. 17) to map these compounds in chemical space. The physicochemical properties of Mycalid compounds are largely overlapping between different structural classes. A large portion of these compounds has lipophilic properties (positive values on PC3) with low aromatic properties (negative values on PC2). The compounds with low aromatic properties paired with low lipophilic properties can be viewed (negative values on both PC2 and PC3). Finally of interest are those with high aromatic properties (positive values on PC2), most of which also correspond to low lipophilic characteristics (negative values on PC3).

The 190 compounds reported to date from members of the family Mycalidae consist of a chemically diverse group of structures (O Fig. 18 and Table 1). Almost half of these (86 compounds) are alkaloids mainly comprised of 2,5-disubstituted pyrrole derivatives and monoindoles. The 2,5-disubstituted pyrrole derivatives are the largest group of compounds isolated from the family with 67 structures reported, most of which differ by the length, branching, and saturation of the 5-alkyl substituents. The majority of the non-alkaloids are either polyketides, terpenoids, or lipids. Polyketides (30 compounds) are mostly dominated by macrolides (16 compounds), in particular the trisoxazole mycalolides. Within the terpenoids (26 compounds), the majority are either cyclic peroxides known as mycaperoxides or the related norterpenoid oxidative degradation products (19 compounds). The lipids are mainly comprised of sterols or steroid-containing compounds (steroidal glycosides). The remaining 19 compounds include some peptides, nucleosides, and nucleobases, among others. Compounds were identified from members of seven subgenera of the genus Mycale, but no compounds were reported from the smaller genus Phlyctaenopora. Almost half (91 compounds) of the compounds reported in the family Mycalidae are from species in the subgenus Mycale (Carmia) ( $\odot$ Fig. 19 and Table 1S, Supporting Information). The majority of these compounds are alkaloids, in particular 2,5-disubstituted pyrrole derivatives. This indicates that members of this subgenus are a good source of pyrrole-2-

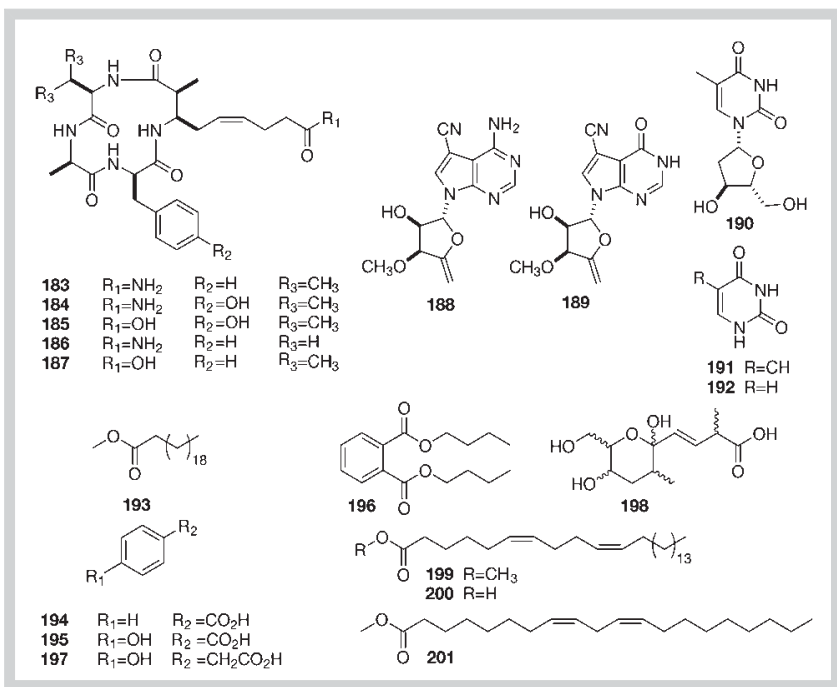

Fig. 16 Chemical structures of cyclic tetrapeptides, nucleosides, nucleobases, and other compounds.

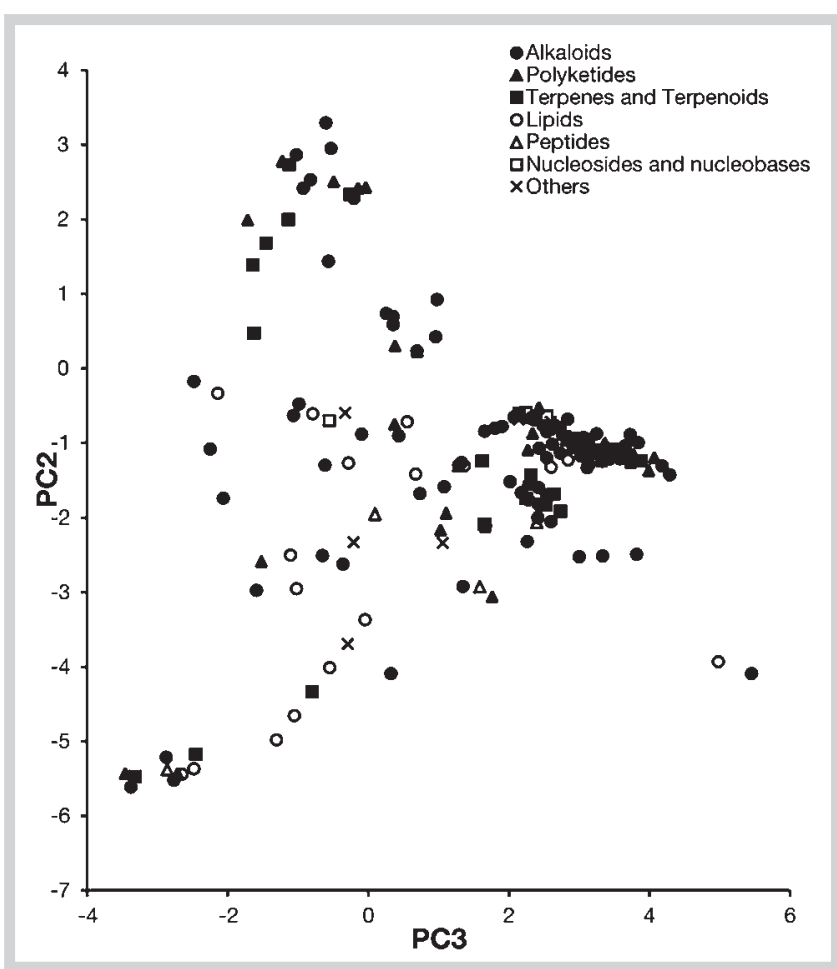

Fig. 17 Plot of principal components (PC2 versus PC3) generated from submitting the SMILES codes to ChemGPS-NP, mapping the compounds in chemical space. PC2 comprises aromatic- and conjugation-related properties with aromatic properties increasing in positive values, and PC3 comprises lipophilicity, polarity, and hydrogen bonding capacity with lipophilic properties increasing in the positive values.

carboxaldehydes and related compounds. The remaining compound classes were found spread throughout the subgenera. It might appear that the subgenus Mycale (Arenochalina) contains a large proportion of lipids, but this is the result of the efforts of one research group isolating the mycalosides and associated ster- 


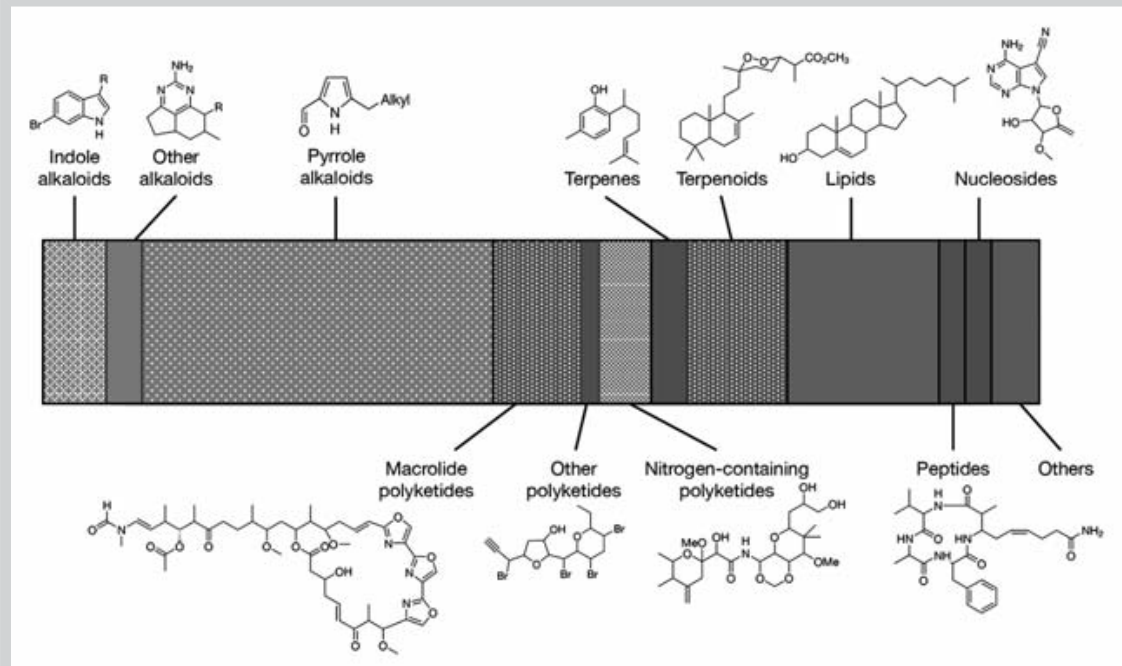

Fig. 18 Structural diversity of Mycalid compounds across compound classes. Shaded regions are proportionate to the number of compounds within each class and structures presented are representative of the compounds observed for each class.

Table 1 Number of compounds of each compound class reported in the family Mycalidae.

\begin{tabular}{lc} 
Compound class & Number of compounds \\
Alkaloids - Indoles & 12 \\
\hline Alkaloids - Other & 7 \\
Alkaloids - Pyrrole derivatives & 67 \\
Polyketides - Macrolides & 16 \\
\hline Polyketides - Others & 4 \\
Polyketides - Containing Nitrogen & 10 \\
Terpenes & 7 \\
Terpenoids & 19 \\
Lipids & 29 \\
Peptides & 5 \\
Nucleosides and Nucleobases & 5 \\
Others & 9 \\
Total & 190
\end{tabular}

ols from a single specimen of M. (Arenochalina) laxissima [125, 134, 135].

Analysis of the geographic distribution of the different compound classes found within the Mycalidae provides no obvious pattern ( Fig. 20 and Table 2S, Supporting Information). This suggests that the production of compounds across the family is not (at least not obviously) affected by geographic location and climatic conditions. It can be seen that some of the oceans are under sampled, with no samples from the South Atlantic Ocean, and only a single specimen from the Southern Ocean that yielded a single lipid. The majority of compounds $(n=90)$ were isolated from the North Pacific Ocean, which is not surprising considering the efforts of research groups located in China and Japan.

\section{Taxonomic Considerations}

$\nabla$

Some of the compound classes including the pyrrole alkaloids, polyketide macrolides, and cyclic peroxides isolated from Mycalid sponges hold potential to aid in sponge taxonomy. Brominated indole alkaloids have been suggested as potentially useful chemotaxonomic indicators for the family Mycalidae [10]. However, their potential might be limited by the distribution of brominated monoindole alkaloids across the sponge class Demospongiae as

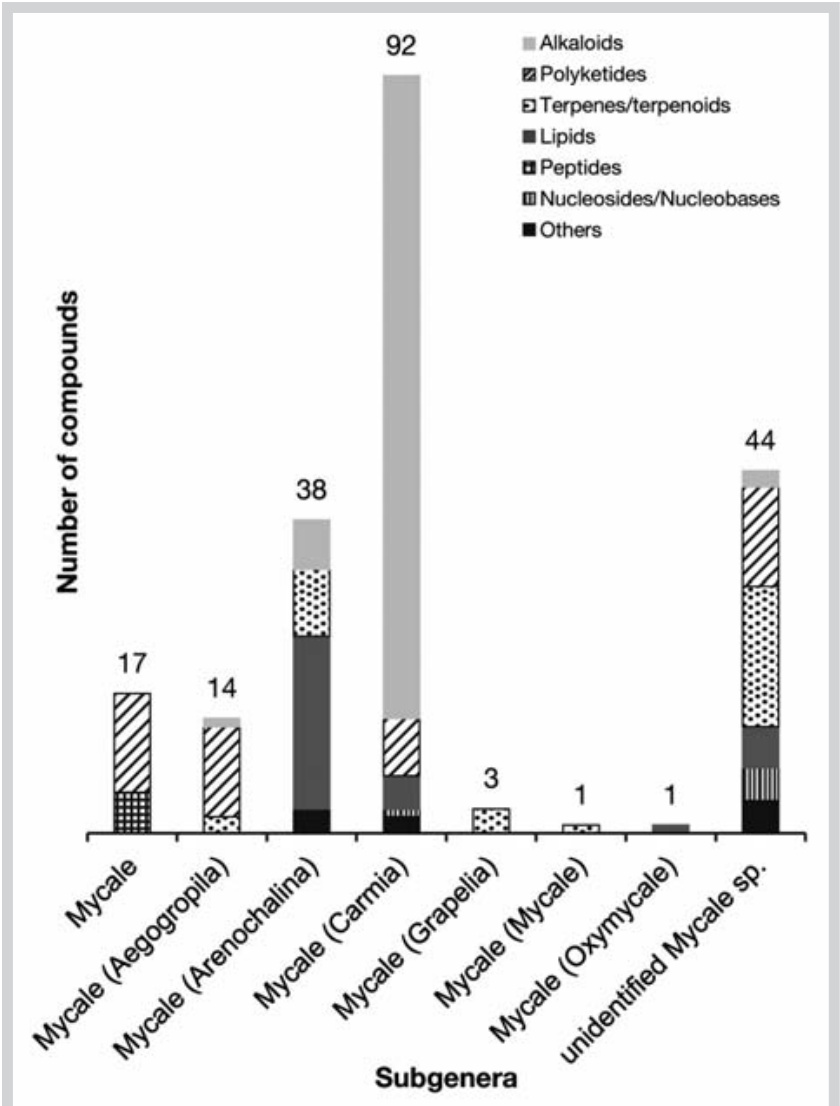

Fig. 19 Number of compounds and division across compound classes for each of the subgenera of the family Mycalidae.

well as across other marine taxa. The 2,5-disubstituted pyrrole derivatives, however, appear to be distinctly sponge compounds that may have a possible restriction to the family Mycalidae (and closely related sponges). A large diversity of structures has been reported, and there are limited reports of related compounds in non-Mycalid sponge taxa, and no reports in other non-sponge taxa (with the exception of the coral-sponge association [31]). This provides evidence that Mycalid sponges could be targeted 


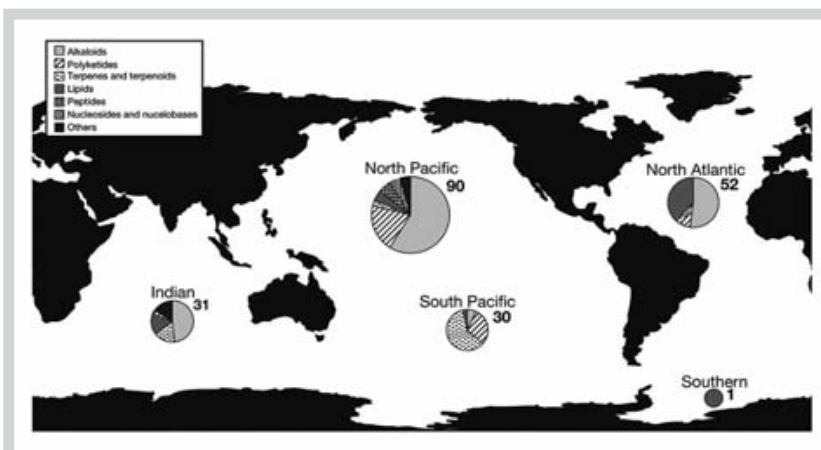

Fig. 20 Geographic distribution of isolated Mycalid compounds across the world oceans, categorised by compound class.

as a good source of 2,5-disubstituted pyrrole derivatives. The mirabilins and related guanidine tricyclic alkaloids appear to be distinctly sponge derived. They have been characterised mainly from the order Poecilosclerida [from the genera Batzella, Monanchora, and Clathria (Isociella)] as well as the orders Biemnida (Biemna) and Axinellida (Acanthella). Despite the uncertainty of mirabilins as true Mycalidae compounds due to questionable specimen identification, guanidine tricyclic alkaloids might still hold potential as taxonomic indicators for this group of Poecilosclerids.

The current survey has shown that researchers are very likely to encounter polyketides (in particular macrolides) in the family Mycalidae, with these compounds widespread throughout the family. Many polyketides are thought to be microbial in origin, which can limit their potential usefulness in sponge taxonomy. There is evidence of cases where sponge-associated microbial communities have displayed species specificity $[152,153]$ and therefore it is possible the resulting co-metabolites might be of taxonomic usefulness. For this to occur the nature of the sponge-microbe association needs to be assessed on a case-bycase basis. Additionally, if these compounds are produced by symbionts this could provide insight into the microbial diversity present within Mycalid sponges and the subsequent uniqueness of their biosynthetic pathways. In some cases it is also thought that sponges possess the ability to further elaborate products of microbial polyketide synthesis, resulting in compounds of mixed biogenetic origin (e.g., $[154,155])$. The mycalolides and other trisoxazole macrolides are so far found in sponges among five orders (Chondrosiida, Dictyoceratida, Poecilosclerida, Suberitida, and Tetractinellida) as well being sequestered by nudibranch predators.

To assess the suitability of the species M. (Carmia) hentscheli for aquaculture, the spatial and temporal variation of three bioactive macrolides, mycalamide A (1), pateamine (2), and peloruside A (3) has been assessed. Variation in the concentration and production of these compounds was observed at different locations indicating the presence of different chemotypes [156,157]. However, the reisolation of these compounds from several different specimens confirms their consistent presence in this sponge species and further suggests that the sponge's macrolide-producing microbial flora may be obligate symbionts.

The 1,2-dioxane ring containing norsesterterpene cyclic peroxides are distinctly sponge metabolites that could be a potential marker for the order Poecilosclerida. Acyclic, monocyclic, and bicyclic structures have been isolated from the genera Diacarnus,
Latrunculia, Negombata, and Sigmosceptrella in addition to Mycale. Their presence suggests this family, in addition to other Poecilosclerid families, would be a good source to target the isolation of peroxy natural products. Peptides are perhaps underrepresented in the family Mycalidae considering the diversity of peptides isolated from sponges as a whole. This might provide some indication of the microbial symbionts of this family with peptides commonly of fungal or cyanobacterial origin.

One last taxonomic consideration is that of appropriate species identification. Sponge taxonomy is notoriously difficult for a non-taxonomist, and requires microscopic and histological analysis for correct identification (and even then it is often challenging). It is common for many sponges to only be identified to genus and remain unidentified at the species level. In terms of this review, it is then possible some of these specimens reported here might be incorrectly identified as Mycalids, and that other true Mycalids might have been misidentified as other sponge taxa. For example, the specimen of $M$. (Arenochalina) mirabilis (reported as Arenochalina mirabilis), after reexamination of the voucher material, appears to possess characters of a Monanchora sp. [43]. As this is the only source of mirabilins in the family Mycalidae, the questionable identification of the specimen makes the presence of these compounds in the family uncertain. It is important to consider the possibility of erroneous species identifications when interpreting the distribution of compounds and relationships among different sponge taxa.

\section{Biologically Active Compounds from the Family Mycalidae} $\nabla$

Of the 190 Mycalid compounds, over half ( $n=99)$ have some type of biological activity reported, and the remaining $(n=91)$ have no reported activity (Fig. 15 and Table 35, Supporting Information). Cytotoxic activities were reported for $90 \%(n=89)$ of the active compounds, with the remaining showing a variety of other types of activity including anti-infective properties (antibacterial, antifungal, antiviral, antimalarial, and nematocidal), protein synthesis and enzyme inhibitions, and immunosuppressive activity. In a few cases, compounds were reported to possess more than one type of bioactivity.

Of the reported activities, $15 \%(n=29)$ exhibited potent activities in the nanomolar range $\left(\mathrm{IC}_{50}\right.$ values $\left.<1 \mu \mathrm{M}\right), 27 \%(\mathrm{n}=52)$ exhibited moderate activities in the low micromolar range $\left(\mathrm{IC}_{50}\right.$ values of $1-20 \mu \mathrm{M})$, and $10 \%(\mathrm{n}=19)$ exhibited low activities (with $\mathrm{IC}_{50}$ values $>20 \mu \mathrm{M}$ ) ( Fig. 21 and Table 4S, Supporting Information). The polyketides accounted for the largest proportion of the potently biologically active compounds $(79 \%, \mathrm{n}=23)$. The alkaloids also contained a large number of active compounds with $82 \%$ ( $n=41$ ) of the moderately active compounds found within this class. Despite the peptides being underrepresented with only five compounds reported, all displayed HDAC inhibitory activity. Only three of the reported terpenes have displayed biological activity, however, considering the biological activity reported for other related endoperoxides, this number could probably be higher since many of the cyclic peroxides remain untested rather than inactive. 


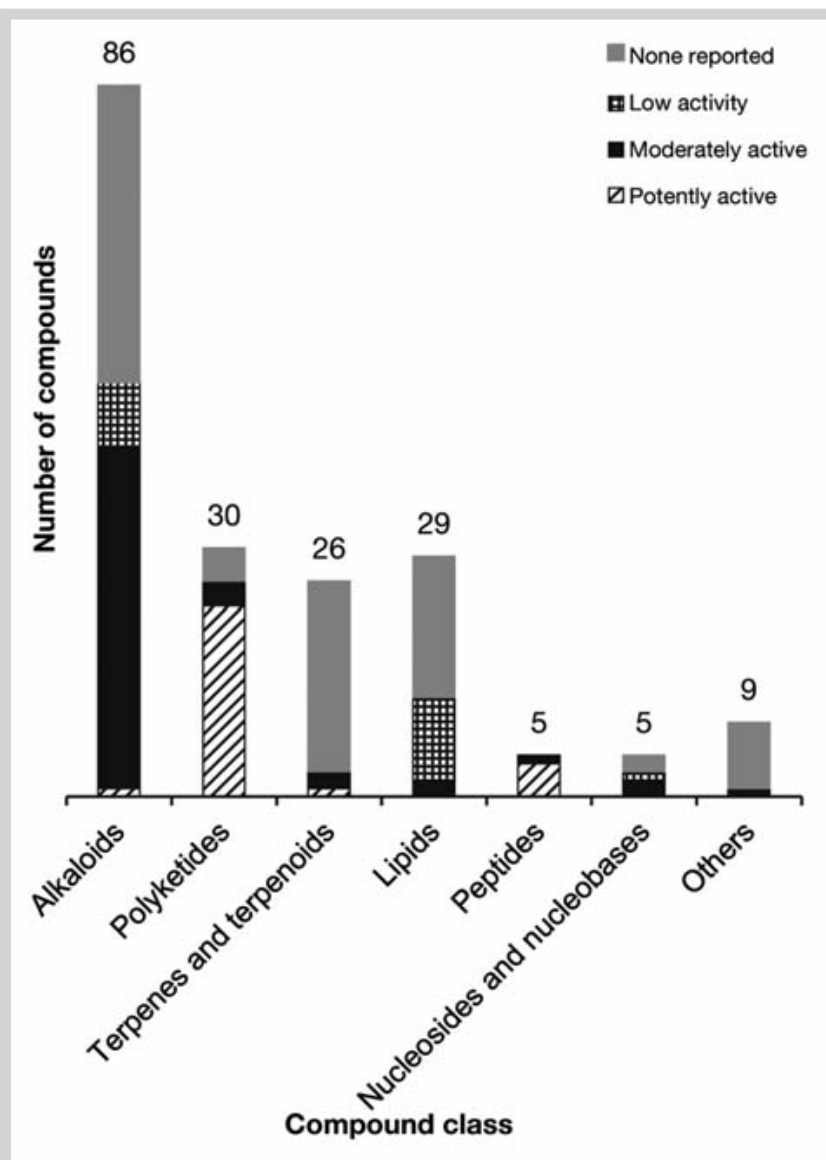

Fig. 21 The distribution of the potency of reported biological activity in each of the compound classes of the family Mycalidae categorised as: potently active $(<1 \mu \mathrm{M})$, moderately active $(1-20 \mu \mathrm{M})$, low activity $(>20 \mu \mathrm{M})$, or no reported activity (none reported).

\section{Conclusions}

$\nabla$

The chemical diversity documented above demonstrates that the family Mycalidae provides a good source of diverse and biologically active natural products. Biodiscovery researchers would do well to consider obtaining collections of Mycalid sponges since they are likely to provide a potential valuable new source of macrocyclic polyketides, many of which are likely to exhibit potent cytotoxicity. Targeted collection of Mycalidae are also likely to provide a lucrative source of pyrrole derivatives, as well as the bicyclic peroxides with unique structures and the potential to exhibit biological activity. Finally, the trisoxazole macrolides, cyclic peroxides, and 2,5-disubstituted pyrrole derivatives might prove useful to assess the higher relationships of the family Mycalidae to other sponge taxa and as chemotaxonomic markers within the family.

\section{Supporting information \\ $\nabla$}

Tabulated data of the number of compounds within each compound class for subgenera, world oceans, biological activity type, and biological potency, and a figure of bioactivity types can be found in Supporting Information (Tables 1S-4S and Fig. 1S). Also provided is the number of publications reporting the isolation of

natural products from the family Mycalidae for each country over the time period 1985-2014 to illustrate the distribution of research efforts (Table 5 S and Fig. 2S).

\section{Acknowledgements}

We thank L. Robertson (Griffith University) for reading a draft manuscript. L.J.H. is grateful to be the recipient of an Australian Postgraduate Award from the Australian Government.

\section{Conflict of Interest}

$\nabla$

The authors declare no conflict of interest.

\section{References}

1 Munro MHG, Blunt JW, Dumdei EJ, Hickford SJH, Lill RE, Li S, Battershill $C N$, Duckworth AR. The discovery and development of marine compounds with pharmaceutical potential. J Biotechnol 1999; 35: 15-25

2 van Soest RWM, Boury-Esnault N, Hooper JNA, Rützler K, de Voogd NJ, Alvarez de Glasby B, Hajdu E, Pisera AB, Manconi R, Schönberg C, Janussen D, Tabachnick KR, Klautau M, Picton B, Kelly M, Vacelet J, Dohrmann M, Díaz MC, Cardenas P. World Porifera Database, 2015. Available at http:// www.marinespecies.org/porifera. Accessed May 25, 2015

3 van Soest RWM, Boury-Esnault N, Vacelet J, Dohrmann M, Erpenbeck D, De Voogd NJ, Santodomingo N, Vanhoorne B, Kelly M, Hooper JNA. Global diversity of sponges (Porifera). PLoS One 2012; 7: e35105

4 van Soest RWM, Hajdu E. Family Mycalidae Lundbeck, 1905. In: Hooper JNA, van Soest RWM, editors. Systema Porifera: a guide to the classification of sponges. New York, USA: Kluwer Academic/Plenum Publishers; 2002: 669-690

5 Perry NB, Blunt JW, Munro MH, Pannell LK. Mycalamide A, an antiviral compound from a New Zealand sponge of the genus Mycale. J Am Chem Soc 1988; 110: 4850-4851

6 Northcote PT, Blunt JW, Munro MHG. Pateamine: a potent cytotoxin from the New Zealand marine sponge, Mycale sp. Tetrahedron Lett 1991; 32: 6411-6414

7 West LM, Northcote PT, Battershill CN. Peloruside A: a potent cytotoxic macrolide isolated from the New Zealand marine sponge Mycale sp. J Org Chem 2000; 65: 445-449

8 Venkatesham U, Rama Rao M, Venkateswarlu Y. New 5-alkylpyrrole-2carboxaldehyde derivatives from the sponge Mycale tenuispiculata. J Nat Prod 2000; 63: 1318-1320

9 Fusetani N, Sugawara T, Matsunaga S, Hirota H. Cytotoxic metabolites of the marine sponge Mycale adhaerens Lambe. J Org Chem 1991; 56: 4971-4974

10 Wang RP, Lin HW, Li LZ, Gao PY, Xu Y, Song SJ. Monoindole alkaloids from a marine sponge Mycale fibrexilis. Biochem Syst Ecol 2012; 43: 210-213

11 Cardellina JH, Nigh D, VanWagenen BC. Plant growth regulatory indoles from the sponges Dysidea etheria and Ulosa ruetzleri. J Nat Prod 1986; 49: 1065-1067

12 Dellar G, Djura P, Sargent MV. Structure and synthesis of a new bromoindole from a marine sponge. J Chem Soc Perkin Trans 1 1981: $1679-1680$

13 Li L, Deng Z, Fu H, Li J, Proksch P, Lin W. Chemcial constituents from the marine sponge Iotrochoto birotulata. Pharmazie 2003; 58: 680-681

14 Dillman RL, Cardellina JH. Aromatic secondary metabolites from the sponge Tedania ignis. J Nat Prod 1991; 54: 1056-1061

15 Guerriero A, D'Ambrosio M, Pietra F, Debitus C, Ribes O. Pteridines, sterols, and indole derivatives from the Lithistid sponge Corallistes undulatus of the Coral sea. J Nat Prod 1993; 56: 1962-1970

16 Guella G, Mancini I, Duhet D, Richer de Forges B, Pietra F. Ethyl 6-bromo3-indolcarboxylate and 3-hydroxyacetal-6-bromoindole, novel bromoindoles from the sponge Pleroma menoui of the Coral sea. Z Naturforsch C 1989; 44: 914-916

17 Capon RJ, Skene C, Vuong D, Lacey E, Gill JH, Heiland K, Friedel T. Equilibrating isomers: bromoindoles and a seco-xanthine encountered during a study of nematocides from the Southern Australian marine sponge Hymeniacidon sp. J Nat Prod 2002; 65: 368-370 
18 Rasmussen T, Jensen J, Anthoni U, Christophersen C, Nielsen PH. Structure and synthesis of bromoindoles from the marine sponge Pseudosuberites hyalinus. J Nat Prod 1993; 56: 1553-1558

19 Bao B, Zhang P, Lee Y, Hong J, Lee CO, Jung JH. Monoindole alkaloids from a marine sponge Spongosorites sp. Mar Drugs 2007; 5: 31-39

20 Rudolph KE, Liberio MS, Davis RA, Carroll AR. Pteridine-, thymidine-, choline-and imidazole-derived alkaloids from the Australian ascidian, Leptoclinides durus. Org Biomol Chem 2013; 11: 261-270

21 Fu X, Schmitz FJ, Tanner RS. Chemical constituents of halophilic facultatively anaerobic bacteria. J Nat Prod 1995; 58: 1950-1954

22 Venkateswarlu Y, Rama Rao M, Farooq Biabani M. 5-Alkylpyrrole-2-carboxaldehydes from the sponges Mycalecarmia monanchrorata and Mycale mytilorum. Indian J Chem B 1996; 35: 876-877

23 Stierle DB, Faulkner DJ. Metabolites of the marine sponge Laxosuberites species. J Org Chem 1980; 45: 4980-4982

24 Ortega MJ, Zubia E, Carballo JL, Salvá J. New cytotoxic metabolites from the sponge Mycale micracanthoxea. Tetrahedron 1997; 53: 331-340

25 Compagnone RS, Oliveri MC, Piña IC, Marques S, Rangel HR, Dagger F, Suárez AI, Gómez M. 5-Alkylpyrrole-2-carboxaldehydes from the Caribbean sponges Mycale microsigmatosa and Desmapsamma anchorata. Nat Prod Lett 1999; 13: 203-211

26 Reddy GB, Dhananjaya N. Chemical investigation of Mycale mytilorum and a study on toxicity and antidiabetic activity of 5-octadecylpyrrole-2-carboxaldehyde. Bioorg Med Chem 2000; 8: 27-36

27 Ortega MJ, Zubía E, Sánchez MC, Salvá J, Carballo JL. Structure and cytotoxicity of new metabolites from the sponge Mycale cecilia. Tetrahedron 2004; 60: 2517-2524

28 Hertiani T, Edrada RA, van Soest RWM, Sudarsono, Muller WEG, Proksch $P$. Chemical investigation on Indonesian marine sponge Mycale phyllophila. Maj Farm Indones 2009; 20: 104-111

29 Mao SC, Liu Y, Morgan JB, Jekabsons MB, Zhou YD, Nagle DG. Lipophilic 2, 5-disubstituted pyrroles from the marine sponge Mycale sp. inhibit mitochondrial respiration and HIF-1 activation. J Nat Prod 2009; 72: 1927-1936

30 Zhou X, Lin X, Guo X, Yang B, Yang XW, Liu Y. Chemical constituents of the sponge Mycale species from South China sea. Rec Nat Prod 2013; 7 : $119-123$

31 Bowden BF, Clezy PS, Coll JC, Ravi BN, Tapiolas DM. Studies of Australian soft corals. XXXIV. A new substituted pyrrole from a soft coral-sponge association. Aust J Chem 1984; 37: 227-230

32 Loukaci A, Muricy G, Brouard JP, Guyot M, Vacelet J, Boury-Esnault N. Chemical divergence between two sibling species of Oscarella (Porifera) from the Mediterranean Sea. Biochem Syst Ecol 2004; 32: 893899

33 Barrow RA, Murray LM, Lim TK, Capon RJ. Mirabilins (A-F): New alkaloids from a Southern Australian marine sponge, Arenochalina mirabilis. Aust J Chem 1996; 49: 767-773

34 Gros E, Al-Mourabit A, Martin MT, Sorres J, Vacelet J, Frederich M, Aknin $M$, Kashman Y, Gauvin-Bialecki A. Netamines H-N, tricyclic alkaloids from the marine sponge Biemna laboutei and their antimalarial activity. J Nat Prod 2014; 77: 818-823

35 El-Naggar M, Conte M, Capon RJ. Mirabilins revisited: polyketide alkaloids from a Southern Australian marine sponge, Clathria sp. Org Biomol Chem 2010; 8: 407-412

36 Patil AD, Freyer AJ, Offen P, Bean MF, Johnson RK. Three new tricyclic guanidine alkaloids from the sponge Batzella sp. J Nat Prod 1997; 60: 704-707

37 Ferreira EG, Wilke DV, Jimenez PC, de Oliveira JR, Pessoa ODL, Silveira ER, Viana FA, Pessoa C, de Moraes MO, Hajdu E, Costa-Lotufo LV. Guanidine alkaloids from Monanchora arbuscula: Chemistry and antitumor potential. Chem Biodivers 2011; 8: 1433-1445

38 Hua HM, Peng J, Fronczek FR, Kelly M, Hamann MT. Crystallographic and NMR studies of antiinfective tricyclic guanidine alkaloids from the sponge Monanchora unguifera. Bioorg Med Chem 2004; 12: 64616464

39 Berlinck RG, Trindade-Silva AE, Santos MF. The chemistry and biology of organic guanidine derivatives. Nat Prod Rep 2012; 29: 1382-1406

40 Grkovic T, Blees JS, Bayer MM, Colburn NH, Thomas CL, Henrich CJ, Peach ML, McMahon JB, Schmid T, Gustafson KR. Tricyclic guanidine alkaloids from the marine sponge Acanthella cavernosa that stabilize the tumor suppressor PDCD4. Mar Drugs 2014; 12: 4593-4601

41 Sorek H, Rudi A, Gueta S, Reyes F, Martin MJ, Aknin M, Gaydou E, Vacelet J, Kashman $Y$. Netamines A-G: seven new tricyclic guanidine alkaloids from the marine sponge Biemna laboutei. Tetrahedron 2006; 62: 8838-8843
42 Capon RJ, Miller M, Rooney F. Mirabilin G: a new alkaloid from a Southern Australian marine sponge, Clathria species. J Nat Prod 2001; 64: 643-644

43 Santos MF, Harper PM, Williams DE, Mesquita JT, Pinto EG, da Costa-Silva TA, Hajdu E, Ferreira AG, Santos RA, Murphy PJ, Andersen RJ, Tempone $A G$, Berlinck $R G$. Anti-parasitic guanidine and pyrimidine alkaloids from the marine sponge Monanchora arbuscula. J Nat Prod 2015; 78: 1101-1112

44 Tavares R, Daloze D, Braekman JC, Hajdu E, Van Soest RWM. 8 $\beta$-Hydroxyptilocaulin, a new guanidine alkaloid from the sponge Monanchora arbuscula. J Nat Prod 1995; 58: 1139-1142

45 Harbour GC, Tymiak AA, Rinehart jr. KL, Shaw PD, Hughes jr. R, Mizsak SA, Coats JH, Zurenko GE, Li LH, Kuentzel SL. Ptilocaulin and isoptilocaulin, antimicrobial and cytotoxic cyclic guanidines from the Caribbean sponge Ptilocaulis aff. P. spiculifer (Lamarck, 1814). J Am Chem Soc 1981; 103: 5604-5606

46 Coello L, Martín MJ, Reyes F. 1, 5-Diazacyclohenicosane, a new cytotoxic metabolite from the marine sponge Mycale sp. Mar Drugs 2009; 7: 445-450

47 Matsunaga S, Sugawara T, Fusetani N. New mycalolides from the marine sponge Mycale magellanica and their interconversion. J Nat Prod 1998; 61: 1164-1167

48 Riego E, Hernández D, Albericio F, Álvarez M. Directly Linked Polyazoles: Important Moieties in Natural Products. Synthesis (Mass) 2005; 12: 1907-1922

49 Fusetani N, Yasumuro K, Matsunaga S, Hashimoto K. Mycalolides A-C hybrid macrolides of ulapualides and halichondramide, from a sponge of the genus Mycale. Tetrahedron Lett 1989; 30: 2809-2812

50 Phuwapraisirisan P, Matsunaga S, van Soest RW, Fusetani N. Isolation of a new mycalolide from the marine sponge Mycale izuensis. J Nat Prod 2002; 65: 942-943

51 Tsukamoto S, Koimaru K, Ohta T. Secomycalolide A: A New Proteasome Inhibitor Isolated from a Marine Sponge of the Genus Mycale. Mar Drugs 2005; 3: 29-35

52 Liu Y, Ji H, Zhang S, Jung JH, Xu T. Trisoxazole macrolides from the sponge Sarcotragus species. Chem Nat Compd 2008; 44: 140-141

53 Rashid MA, Gustafson KR, Cardeilina JH, Boyd MR. Mycalolides D and E, new cytotoxic macrolides from a collection of the stony coral Tubastrea faulkneri. J Nat Prod 1995; 58: 1120-1125

54 Matsunaga S, Nogata Y, Fusetani N. Thiomycalolides: new cytotoxic trisoxazole-containing macrolides isolated from a marine sponge Mycale sp. J Nat Prod 1998; 61: 663-666

55 Sirirak T, Kittiwisut S, Janma C, Yuenyongsawad S, Suwanborirux K, Plubrukarn A. Kabiramides J and K, trisoxazole macrolides from the sponge Pachastrissa nux. J Nat Prod 2011; 74: 1288-1292

56 Kobayashi J, Murata O, Shigemori H, Sasaki T. Jaspisamides A-C, new cytotoxic macrolides from the Okinawan sponge Jaspis sp. J Nat Prod 1993; 56: 787-791

57 Kernan MR, Faulkner DJ. Halichondramide, an antifungal macrolide from the sponge Halichondria sp. Tetrahedron Lett 1987; 28: 28092812

58 Kernan MR, Molinski TF, Faulkner DJ. Macrocyclic antifungal metabolites from the Spanish dancer nudibranch Hexabranchus sanguineus and sponges of the genus Halichondria. J Org Chem 1988; 53: 5014 5020

59 Kobayashi J, Tsuda M, Fuse H, Sasaki T, Mikami Y. Halishigamides A-D, new cytotoxic oxazole-containing metabolites from Okinawan sponge Halichondria sp. J Nat Prod 1997; 60: 150-154

60 Shin J, Lee HS, Kim JY, Shin HJ, Ahn JW, Paul VJ. New macrolides from the sponge Chondrosia corticata. J Nat Prod 2004; 67: 1889-1892

61 Matsunaga S, Fusetani N, Hashimoto K, Koseki K, Noma M. Bioactive marine metabolites. Part 13 . Kabiramide $C$, a novel antifungal macrolide from nudibranch eggmasses. J Am Chem Soc 1986; 108: 847-849

62 Matsunaga S, Fusetani N, Hashimoto K, Koseki K, Noma M, Noguchi H, Sankawa $U$. Further kabiramides and halichondramides, cytotoxic macrolides embracing trisoxazole, from the Hexabranchus egg masses. J Org Chem 1989; 54: 1360-1363

63 Roesener JA, Scheuer PJ. Ulapualide A and B, extraordinary antitumor macrolides from nudibranch eggmasses. J Am Chem Soc 1986; 108: 846-847

64 Suenaga K, Kimura T, Kuroda T, Matsui K, Miya S, Kuribayashi S, Sakakura A, Kigoshi $H$. Synthesis and biological activity of mycalolide analogs. Tetrahedron 2006; 62: 8278-8290

65 Saito S, Watabe S, Ozaki H, Fusetani N, Karaki H. Mycalolide B, a nove actin depolymerizing agent. J Biol Chem 1994; 269: 29710-29714 
66 Hori M, Saito S, Shin YZ, Ozaki H, Fusetani N, Karaki H. Mycalolide-B, a novel and specific inhibitor of actomyosin ATPase isolated from marine sponge. FEBS Lett 1993; 322: 151-154

67 Schmitz FJ, Gunasekera SP, Yalamanchili G, Hossain MB, van der Helm D. Tedanolide: a potent cytotoxic macrolide from the Caribbean sponge Tedania ignis. J Am Chem Soc 1984; 106: 7251-7252

68 Chevallier C, Bugni TS, Feng X, Harper MK, Orendt AM, Ireland CM. Tedanolide C: a potent new 18 -membered-ring cytotoxic macrolide isolated from the Papua New Guinea marine sponge Ircinia sp. J Org Chem 2006; 71: 2510-2513

69 Whitson EL, Pluchino KM, Hall MD, McMahon JB, McKee TC. New candidaspongiolides, tedanolide analogues that selectively inhibit melanoma cell growth. Org Lett 2011; 13: 3518-3521

70 Nishimura S, Matsunaga S, Yoshida M, Hirota H, Yokoyama S, Fusetani N. 13-Deoxytedanolide, a marine sponge-derived antitumor macrolide, binds to the 60 S large ribosomal subunit. Bioorg Med Chem 2005; 13 : 449-454

71 Singh AJ, Razzak M, Teesdale-Spittle P, Gaitanos TN, Wilmes A, Paterson I, Goodman JM, Miller JH, Northcote PT. Structure-activity studies of the pelorusides: new congeners and semi-synthetic analogues. Org Biomol Chem 2011; 9: 4456-4466

72 Clardy J. Stopping trouble before it starts. ACS Chem Biol 2006; 1: 1719

73 Romo D, Rzasa RM, Shea HA, Park K, Langenhan JM, Sun L, Akhiezer A, Liu $J O$. Total synthesis and immunosuppressive activity of (-)-pateamine A and related compounds: Implementation of a $\beta$-lactam-based macrocyclization. J Am Chem Soc 1998; 120: 12237-12254

74 Singh AJ, Xu CX, Xu X, West LM, Wilmes A, Chan A, Hamel E, Miller JH, Northcote PT, Ghosh AK. Peloruside B, a potent antitumor macrolide from the New Zealand marine sponge Mycale hentscheli: isolation, structure, total synthesis, and bioactivity. J Org Chem 2009; 75: 2-10

75 Hood KA, West LM, Rouwé B, Northcote PT, Berridge MV, Wakefield SJ, Miller JH. Peloruside A, a novel antimitotic agent with paclitaxel-like microtubule-stabilizing activity. Cancer Res 2002; 62: 3356-3360

76 Miller JH, Singh AJ, Northcote PT. Microtubule-stabilizing drugs from marine sponges: focus on peloruside A and zampanolide. Mar Drugs 2010; 8: 1059-1079

77 Perry NB, Blunt JW, Munro MH, Thompson AM. Antiviral and antitumor agents from a New Zealand sponge, Mycale sp. 2. Structures and solution conformations of mycalamides A and B. J Org Chem 1990; 55: 223-227

78 West LM, Northcote PT, Hood KA, Miller JH, Page MJ. Mycalamide D, a new cytotoxic amide from the New Zealand marine sponge Mycale species. J Nat Prod 2000; 63: 707-709

79 Venturi V, Davies C, Singh AJ, Matthews JH, Bellows DS, Northcote PT, Keyzers RA, Teesdale-Spittle $P H$. The protein synthesis inhibitors mycalamides $\mathrm{A}$ and $\mathrm{E}$ have limited susceptibility toward the drug efflux network. J Biochem Mol Toxicol 2012; 26: 94-100

80 Simpson JS, Garson MJ, Blunt JW, Munro MHG, Hooper JNA. Mycalamides $C$ and D, cytotoxic compounds from the marine sponge Stylinos n. species. J Nat Prod 2000; 63: 704-706

81 Dyshlovoy SA, Fedorov SN, Kalinovsky AI, Shubina LK, Bokemeyer C, Stonik VA, Honecker F. Mycalamide A shows cytotoxic properties and prevents EGF-induced neoplastic transformation through inhibition of nuclear factors. Mar Drugs 2012; 10: 1212-1224

82 Burres NS, Clement JJ. Antitumor activity and mechanism of action of the novel marine natural products mycalamide-A and-B and onnamide. Cancer Res 1989; 49: 2935-2940

83 Hood $K$, West L, Northcote P, Berridge M, Miller J. Induction of apoptosis by the marine sponge (Mycale) metabolites, mycalamide A and pateamine. Apoptosis 2001; 6: 207-219

84 Phuwapraisirisan P, Matsunaga S, Fusetani N. Mycapolyols A-F, new cytotoxic metabolites of mixed biogenesis from the marine sponge $M y$ cale izuensis. Org Lett 2005; 7: 2233-2236

85 Pettit GR, Kamano Y, Dufresne C, Cerny RL, Herald CL, Schmidt JM. Isolation and structure of the cytostatic linear depsipeptide dolastatin 15. J Org Chem 1989; 54: 6005-6006

86 Cardellina JH, Marner FJ, Moore RE. Malyngamide A, a novel chlorinated metabolite of the marine cyanophyte Lyngbya majuscula. J Am Chem Soc 1979; 101: 240-242

87 Simmons TL, McPhail KL, Ortega-Barría E, Mooberry SL, Gerwick WH. Belamide $A$, a new antimitotic tetrapeptide from a Panamanian marine cyanobacterium. Tetrahedron Lett 2006; 47: 3387-3390
88 Teta $R$, Irollo E, Della Sala G, Pirozzi G, Mangoni A, Costantino V. Smenamides A and B, chlorinated peptide/polyketide hybrids containing a dolapyrrolidinone unit from the Caribbean sponge Smenospongia aurea. Evaluation of their role as leads in antitumor drug research. Mar Drugs 2013; 11: 4451-4463

89 Giordano F, Mayol L, Notaro G, Piccialli V, Sica D. Structure and absolute configuration of two new polybrominated C15 acetogenins from the sponge Mycale rotalis. J Chem Soc Chem Commun 1990; 1990: 1559-1561

90 Notaro G, Piccialli V, Sica D, Mayol L, Giordano F. A further C15 nonterpenoid polybromoether from the encrusting sponge Mycale rotalis. J Nat Prod 1992; 55: 626-632

91 Imre S, Aydogmus Z, Guner H, Lotter H, Wagner H. Polybrominated non-terpenoid C15 compounds from Laurencia paniculata and Laurencia obtusa. Z Naturforsch C 1995; 50: 743-747

92 Suzuki M, Sasage Y, Ikura M, Hikichi K, Kurosawa E. Structure revision of okamurallene and structure elucidation of further C15 non-terpenoid bromoallenes from Laurencia intricata. Phytochemistry 1989; 28: $2145-2148$

93 Butler M, Capon R, Nadeson R, Beveridge A. Aromatic bisabolenes from an Australian marine sponge, Arenochalina sp. J Nat Prod 1991; 54: 619-623

94 McEnroe FJ, Fenical W. Structures and synthesis of some new antibacterial sesquiterpenoids from the gorgonian coral Pseudopterogorgia rigida. Tetrahedron 1978; 34: 1661-1664

95 Wright AE, Pomponi SA, McConnell OJ, Kohmoto S, McCarthy PJ. (+)-Curcuphenol and (+)-curcudiol, sesquiterpene phenols from shallow and deep water collections of the marine sponge Didiscus flavus. J Nat Prod 1987; 50: 976-978

96 Peng J, Franzblau SG, Zhang F, Hamann MT. Novel sesquiterpenes and a lactone from the Jamaican sponge Myrmekioderma styx. Tetrahedron Lett 2002; 43: 9699-9702

97 Georgantea P, Ioannou E, Vagias C, Roussis V. Bisabolane and chamigrane sesquiterpenes from the soft coral Pseudopterogorgia rigida. Phytochem Lett 2014; 8: 86-91

98 Gaspar H, Feio SS, Rodrigues AI, Van Soest RWM. Antifungal activity of (+)-curcuphenol, a metabolite from the marine sponge Didiscus oxeata. Mar Drugs 2004; 2: 8-13

99 Corriero G, Madaio A, Mayol L, Piccialli V, Sica D. Rotalin A and B, two novel diterpene metabolites from the encrusting Mediterranean sponge Mycale rotalis (Bowerbank). Tetrahedron 1989; 45: 277-288

100 Rudi A, Benayahu Y, Kashman Y. Mycgranol, a new diterpene from the marine sponge Mycale aff. graveleyi. J Nat Prod 2005; 68: 280-281

101 Fattorusso E, Romano A, Taglialatela-Scafati O, Bavestrello G, Bonelli $P$ Calcinai B. Coelodiol and coeloic acid, ent-isocopalane diterpenes from the Indonesian sponge Coelocarteria cfr. singaporensis. Tetrahedron Lett 2006; 47: 2197-2200

102 Gavagnin M, Ungur N, Castelluccio F, Muniain C, Cimino G. New minor diterpenoid diacylglycerols from the skin of the nudibranch Anisodoris fontaini. J Nat Prod 1999; 62: 269-274

103 Zubía E, Gavagnin M, Scognamiglio G, Cimino G, Giusto GB. Spongiane and ent-isocopalane diterpenoids from the Mediterranean sponge Spongia zimocca. J Nat Prod 1994; 57: 725-731

104 Capon RJ. Two new norsesterterpene cyclic peroxides from a marine sponge, Mycale (Carmia) cf. spongiosa. J Nat Prod 1991; 54: 190-195

105 Higa T, Kuniyoshi M. Biologically active terpenoids from sponges. In: Fingerman M, Nagabhushanam R, editors. Biomaterials from aquatic and terrestrial organisms. Enfield, NH, USA: Science Publishers; 2006: 393-450

106 Capon RJ, Rochfort SJ, Ovenden SP. Cyclic peroxides and related norterpenes from a southern Australian marine sponge, Mycale sp. J Nat Prod 1997; 60: 1261-1264

107 Capon RJ, Macleod JK. Structural and stereochemical studies on marine norterpene cyclic peroxides. Tetrahedron 1985; 41: 3391-3404

108 Albericci M, Braekman JC, Daloze D, Tursch B. Chemical studies of marine invertebrates-XLV: The chemistry of three norsesterterpene peroxides from the sponge Sigmosceptrella laevis. Tetrahedron 1982; 38 : 1881-1890

109 Albericci M, Collart-Lempereur M, Braekman JC, Dalcze D, Tursch B, Declercq J, Germain G, Van Meerssche M. Chemical studies of marine invertebrates. XLI. Sigmosceptrellin-A methyl ester a nor-sesterterpenoid peroxide from the sponge Sigmosceptrella laevis. Tetrahedron Lett 1979; 29: 2687-2690

110 Capon RJ, MacLeod JK. Structural and stereochemical studies on marine norterpene cyclic peroxides, Part 2. J Nat Prod 1987; 50: 225-229 
111 Tanaka J, Higa T, Suwanborirux K, Kokpol U, Bernardinelli G, Jefford CW. Bioactive norsesterterpene 1, 2-dioxanes from a Thai sponge, Mycale sp. J Org Chem 1993; 58: 2999-3002

112 Capon RJ, Rochfort SJ, Ovenden SP, Metzger RP. Mycaperoxides F and G and a related norterpene ketone from southern Australian marine sponges, Mycale species. J Nat Prod 1998; 61: 525-528

113 Phuwapraisirisan P, Matsunaga S, Fusetani N, Chaitanawisuti N, Kritsanapuntu S, Menasveta P. Mycaperoxide $\mathrm{H}$, a new cytotoxic norsesterterpene peroxide from a Thai marine sponge Mycale sp. J Nat Prod 2003; 66: 289-291

114 Salmoun M, Braekman JC, Dewelle J, Darro F, Kiss R, De Voogd NJ, Van Soest RWM. New terpenoids from two Indonesian marine sponges. Nat Prod Res 2007; 21: 149-155

115 Youssef DTA. Tasnemoxides A-C, new cytotoxic cyclic norsesterterpene peroxides from the Red Sea sponge Diacarnus erythraenus. J Nat Prod 2004; 67: 112-114

116 Ibrahim SR, Ebel $R$, Wray V, Müller WE, Edrada-Ebel R, Proksch P. Diacarperoxides, norterpene cyclic peroxides from the sponge Diacarnus megaspinorhabdosa. J Nat Prod 2008; 71: 1358-1364

117 Capon RJ, MacLeod JK, Willis AC. Trunculins A and B, norsesterterpene cyclic peroxides from a marine sponge, Latrunculia brevis. J Org Chem 1987; 52: 339-342

118 Chao CH, Chou KJ, Wang GH, Wu YC, Wang LH, Chen JP, Sheu JH, Sung PJ. Norterpenoids and related peroxides from the Formosan marine sponge Negombata corticata. J Nat Prod 2010; 73: 1538-1543

119 Ovenden SP, Capon RJ. Nuapapuin A and sigmosceptrellins D and E: new norterpene cyclic peroxides from a Southern Australian marine sponge, Sigmosceptrella sp. J Nat Prod 1999; 62: 214-218

120 Hattori T, Adachi K, Shizuri Y. New ceramide from marine sponge Haliclona koremella and related compounds as antifouling substances against macroalgae. J Nat Prod 1998; 61: 823-826

121 Muralidhar P, Radhika P, Krishna N, Rao DV, Rao CB. Sphingolipids from marine organisms: a review. Nat Prod Sci 2003; 9: 117-142

122 Cutignano A, Nuzzo G, D’Angelo D, Borbone E, Fusco A, Fontana A. Mycalol: a natural lipid with promising cytotoxic properties against human anaplastic thyroid carcinoma cells. Angew Chem Int Ed Engl 2013: 125: 9426-9430

123 Seetharamsingh B, Rajamohanan P, Reddy DS. Total Synthesis and structural revision of mycalol, an anticancer natural product from the marine source. Org Lett 2015; 17: 1652-1655

124 Magnusson CD, Haraldsson GG. Ether lipids. Chem Phys Lipids 2011; 164: $315-340$

125 Antonov AS, Afiyatullov SS, Kalinovsky AI, Ponomarenko LP, Dmitrenok PS, Aminin DL, Agafonova IG, Stonik VA. Mycalosides B-I, eight new spermostatic steroid oligoglycosides from the sponge Mycale laxissima. J Nat Prod 2003; 66: 1082-1088

126 Zhou X, Sun J, Ma W, Fang W, Chen Z, Yang B, Liu Y. Bioactivities of six sterols isolated from marine invertebrates. Pharm Biol 2014; 52: 187 190

127 Mohamed GA, Abd-Elrazek AE, Hassanean HA, Alahdal AM, Almohammadi $A$, Youssef DT. New fatty acids from the Red Sea sponge Mycale euplectellioides. Nat Prod Res 2014; 28: 1082-1090

128 Rochfort SJ, Gable RW, Capon RJ. Mycalone: a new steroidal lactone from a Southern Australian marine sponge, Mycale sp. Aust J Chem 1996; 49: 715-718

129 Stonard RJ, Petrovich JC, Andersen RJ. A new C26 sterol peroxide from the opisthobranch mollusk Adalaria sp. and the sea pen Virgularia sp. Steroids 1980; 36: 81-86

130 Findlay JA, Patil AD. A novel sterol peroxide from the sea anenome Metridium senile. Steroids 1984; 44: 261-265

131 Jiménez C, Quiñoá E, Castedo L, Riguera R. Epidioxy sterols from the tunicates Dendrodoa grossularia and Ascidiella aspersa and the Gastropoda Aplysia depilans and Aplysia punctata. J Nat Prod 1986; 49: 905-909

132 Mansoor TA, Hong J, Lee CO, Bae SJ, Im KS, Jung JH. Cytotoxic sterol derivatives from a marine sponge Homaxinella sp. J Nat Prod 2005; 68 : 331-336

133 Perianayagam JB, Sharma S, Pillai K, Pandurangan A, Kesavan D. Evaluation of antimicrobial activity of ethanol extract and compounds isolated from Trichodesma indicum (Linn.) R. Br. root. J Ethnopharmacol 2012; 142: 283-286

134 Afiyatullov SS, Antonov AS, Kalinovsky AI, Dmitrenok PS. Two new steroid oligoglycosides from the Caribbean sponge Mycale laxissima. Nat Prod Commun 2008; 3: 1581-1586
135 Kalinovsky AI, Antonov AS, Afiyatullov SS, Dmitrenok PS, Evtuschenko EV, Stonik VA. Mycaloside A, a new steroid oligoglycoside with an unprecedented structure from the Caribbean sponge Mycale laxissima. Tetrahedron Lett 2002; 43: 523-525

136 Antonov AS, Kalinovsky AI, Stonik VA. Ulososide B, a new unusual norlanostane-triterpene glycoside and its genuine aglycone from the Madagascar sponge Ulosa sp. Tetrahedron Lett 1998; 39: 3807-3808

137 Cachet N, Regalado EL, Genta-Jouve G, Mehiri M, Amade P, Thomas OP. Steroidal glycosides from the marine sponge Pandaros acanthifolium. Steroids 2009; 74: 746-750

138 Campagnuolo C, Fattorusso E, Taglialatela-Scafati O. Feroxosides A-B, two norlanostane tetraglycosides from the Caribbean sponge Ectyoplasia ferox. Tetrahedron 2001; 57: 4049-4055

139 Kalinin VI, Ivanchina NV, Krasokhin VB, Makarieva TN, Stonik VA. Glycosides from marine sponges (Porifera, Demospongiae): structures, taxonomical distribution, biological activities and biological roles. Mar Drugs 2012; 10: 1671-1710

140 Nakao Y, Yoshida S, Matsunaga S, Shindoh N, Terada Y, Nagai K, Yamashita JK, Ganesan A, van Soest RWM, Fusetani N. Azumamides A-E: histone deacetylase inhibitory cyclic tetrapeptides from the marine sponge Mycale izuensis. Angew Chem Int Ed Engl 2006; 118: 7715-7719

141 Fusetani N, Matsunaga S. Bioactive sponge peptides. Chem Rev 1993; 93: 1793-1806

142 Itazaki H, Nagashima K, Sugita K, Yoshida H, Kawamura Y, Yasuda $Y$ Matsumoto K, Ishii K, Uotani N, Nakai H, Terui A, Yoshimatsu S, Ikenishi $Y$, Nakagawa Y. Isolation and structural elucidation of new cyclotetrapeptides, trapoxins $\mathrm{A}$ and $\mathrm{B}$, having detransformation activities as antitumor agents. J Antibiot (Tokyo) 1990; 43: 1524-1532

143 Singh SB, Zink DL, Polishook JD, Dombrowski AW, Darkin-Rattray SJ, Schmatz DM, Goetz MA. Apicidins: Novel cyclic tetrapeptides as coccidiostats and antimalarial agents from Fusarium pallidoroseum. Tetrahedron Lett 1996; 37: 8077-8080

$144 \mathrm{Gu}$ W, Cueto M, Jensen PR, Fenical W, Silverman RB. Microsporins A and $B$ : new histone deacetylase inhibitors from the marine-derived fungus Microsporum cf. gypseum and the solid-phase synthesis of microsporin A. Tetrahedron 2007; 63: 6535-6541

145 Degenkolb T, Gams W, Brückner H. Natural cyclopeptaibiotics and related cyclic tetrapeptides: structural diversity and future prospects. Chem Biodivers 2008; 5: 693-706

146 Newman DJ, Cragg GM. Bioactive macrocycles from nature. In: Levin J, editor. Macrocycles in drug discovery. Cambridge, UK: RSC Publishing; 2014

147 Kato Y, Fusetani N, Matsunaga S, Hashimoto K. Bioactive marine metabolites IX. Mycalisines A and B, novel nucleosides which inhibit cell division of fertilized starfish eggs, from the marine sponge Mycale sp. Tetrahedron Lett 1985; 26: 3483-3486

148 Isono K. Nucleoside antibiotics: structure, biological activity, and biosynthesis. J Antibiot (Tokyo) 1988; 41: 1711-1739

149 McCarty RM, Bandarian V. Biosynthesis of pyrrolopyrimidines. Bioorg Chem 2012; 43: 15-25

150 Larsson J, Gottfries J, Muresan S, Backlund A. ChemGPS-NP: tuned for navigation in biologically relevant chemical space. J Nat Prod 2007; 70: 789-794

151 Rosén J, Lövgren A, Kogej T, Muresan S, Gottfries J, Backlund A. ChemGPS-NPWeb: chemical space navigation online. J Comput Aided Mol Des 2009; 23: 253-259

152 Lee OO, Wang Y, Yang J, Lafi FF, Al-Suwailem A, Qian PY. Pyrosequencing reveals highly diverse and species-specific microbial communities in sponges from the Red Sea. ISME J 2011; 5: 650-664

153 Reveillaud J, Maignien L, Eren AM, Huber JA, Apprill A, Sogin ML, Vanreusel $A$. Host-specificity among abundant and rare taxa in the sponge microbiome. ISME J 2014; 8: 1198-1209

154 Guella G, Pietra F. Rogiolenyne A, B, and C: the first branched marine $\mathrm{C} 15$ acetogenins. Isolation from the red seaweed Laurencia microcladia or the sponge Spongia zimocca of II Rogiolo. Helv Chim Acta 1991; 74: $47-54$

155 Taylor RE. Tedanolide and the evolution of polyketide inhibitors of eukaryotic protein synthesis. Nat Prod Rep 2008; 25: 854-861

156 Page M, West L, Northcote P, Battershill C, Kelly M. Spatial and temporal variability of cytotoxic metabolites in populations of the New Zealand sponge Mycale hentscheli. J Chem Ecol 2005; 31: 1161-1174

157 Page MJ, Northcote PT, Webb VL, Mackey S, Handley SJ. Aquaculture trials for the production of biologically active metabolites in the New Zealand sponge Mycale hentscheli (Demospongiae: Poecilosclerida). Aquaculture 2005; 250: 256-269 